\title{
Cathrine Boerseth
}

Spatial dynamics and characterization of the ichthyoplankton community of natural and artificial reef environments on the coast of Paraná state, south Brazil.

Dissertação apresentada ao Instituto Oceanográfico da Universidade de São Paulo, como parte dos requisitos para obtenção do título de Mestre em Ciências, Programa de Oceanografia, área de Oceanografia Biológica.

Orientador: Prof. Dr. Frederico Brandini

São Paulo 



\section{Cathrine Boerseth}

Spatial dynamics and characterization of the ichthyoplankton community of natural and artificial reef environments on the coast of Paraná state, south Brazil.

Dissertação apresentada ao Instituto Oceanográfico da Universidade de São Paulo, como parte dos requisitos para obtenção do título de Mestre em Ciências, Programa de Oceanografia, área de Oceanografia Biológica.

Orientador: Prof. Dr. Frederico Brandini

São Paulo 


\title{
Universidade de São Paulo \\ Instituto Oceanográfico
}

\begin{abstract}
Spatial dynamics and characterization of the ichthyoplankton community of natural and artificial reef environments on the coast of Paraná state, south Brazil.
\end{abstract}

Cathrine Boerseth

Dissertação apresentada ao Instituto Oceanográfico da Universidade de São Paulo, como parte dos requisitos para obtenção do título de Mestre em Ciências, Programa de Oceanografia, área de Oceanografia Biológica.

\section{Versão corrigida}

Julgada em ___ I__ por:

$\operatorname{Prof}(\mathrm{a}) \cdot \operatorname{Dr}(\mathrm{a}) . \quad$ Conceito

$\operatorname{Prof}(\mathrm{a}) . \operatorname{Dr}(\mathrm{a})$.

Conceito

Prof(a). Dr(a).

Conceito 
"So long and thanks for all the fish"

Douglas Adams, Hitchhiker's guide to the Galaxy 


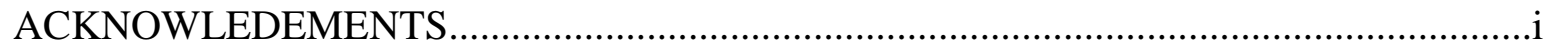

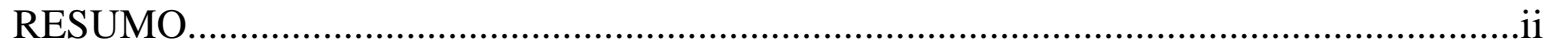

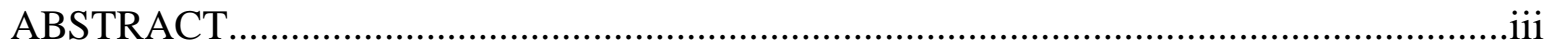

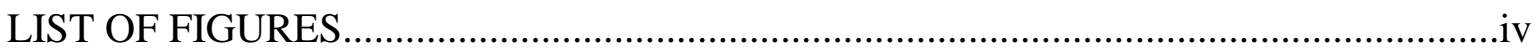

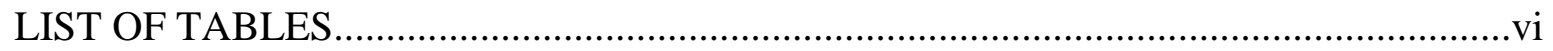

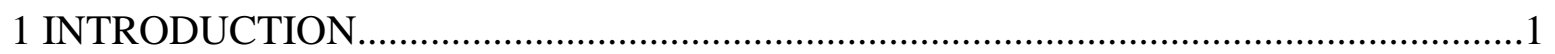

1.1 Purpose and objectives of this research..............................................................5

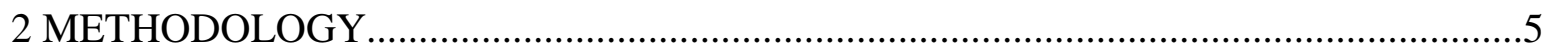

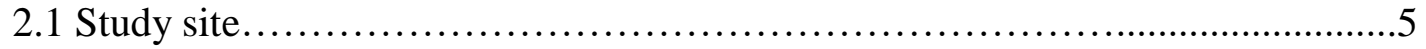

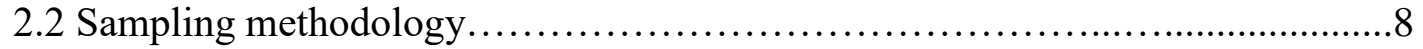

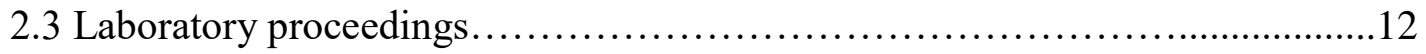

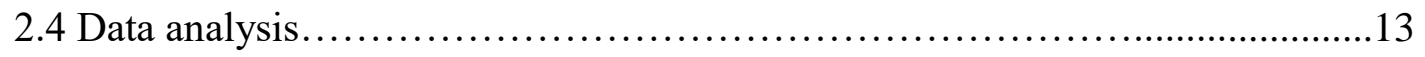

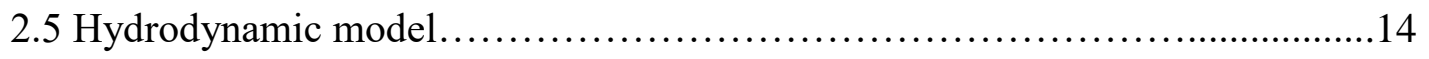

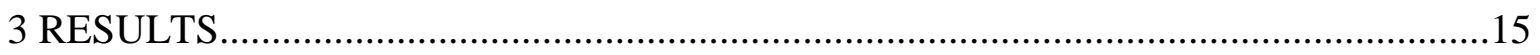

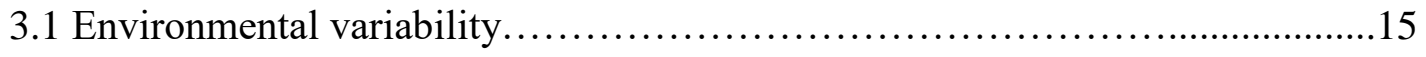

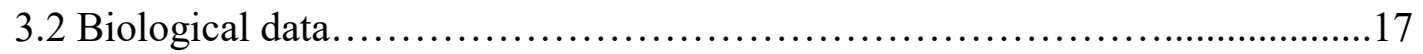

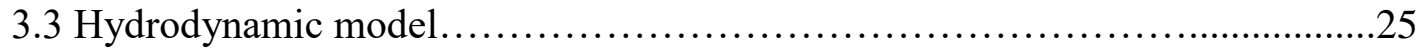

4 DISCUSSION

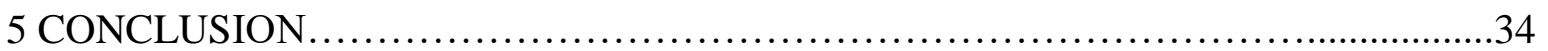

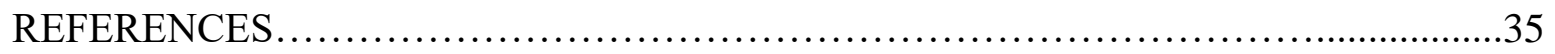

APPENDIX A 


\section{ACKNOWLEDEMENTS}

I would like to thank my advisor, Prof. Dr. Frederico P. Brandini for taking me on as a student and for all his help and encouragements.

To Janaína Bumbeer for welcoming me in Pontal and helping me get a good start, and to everyone else of the MarBrasil Association and REBIMAR team for their assistance with field work; especially to Robin Loose for his diving expertise and boatmanship.

To Ricardo de Camargo for his work with the hydrodynamic model.

To Claudia Akemi Namiki for all the help with identification of fish larvae and continued encouragement.

To Maria de Lourdes Zani Teixeira for all her invaluable help and advice.

To Ana Paula Dourado Evangelista and the others at the post-graduation office for helping me through the boreoarctic jungle.

And lastly, a special thank you to everyone else who have contributed in some way with moral and/or practical support along the way. 


\section{RESUMO}

Recifes Artificiais (RA) foram implantados na plataforma interna do Paraná, sul do Brasil, para atuar como unidades anti-arrasto e para oferecer habitat e abrigo para a fauna local, na tentativa de recuperar a biodiversidade marinha ameaçada pelo pesca de arrasto. O principal objetivo deste estudo foi oferecer uma primeira caracterização da assembleia ictioplanctônica associada aos RAs e ao arquipélago de Currais. Coletas foram realizadas utilizando duas metodologias; 1) rede de plâncton acoplado a uma "scooter" subaquática e; 2) armadilhas de luz. Excursões amostrais foram realizadas entre 31.07.14 e 04.04.16. Um total de 13 famílias e 11 espécies de peixes representadas no ictioplâncton foram identificadas. Foi registrada a primeira ocorrência do blenídeo invasivo Omobranchus punctatus. A abundância de ictioplâncton foi maior em amostras dos RAs comparado às coletas em área-controle; 63\% das larvas capturadas nos RAs foram de espécies recifais. Um modelo hidrodinâmico forneceu uma visão sobre as trajetórias de dispersão larval e conectividade ecológica na região. Os resultados deste estudo podem ser usados para melhor definir diretrizes para o uso sustentável dos RAs e do arquipélago de Currais, um Parque Nacional Marinho desde 2013.

PALAVRAS CHAVE: larvas de peixe; peixes recifais; armadilha de luz; Currais; Atlântico Sul 


\begin{abstract}
.
Artificial reefs (ARs) have been deployed on the inner shelf of Paraná State, south Brazil, to recuperate marine biodiversity and as protection against destructive trawling activities. The purpose of this study was to offer a first characterization of the ichthyoplankton community associated with the ARs and the adjacent archipelago of Currais. Two sampling methodologies were used; 1) plankton net attached to an underwater scooter and; 2) light-traps. A hydrodynamic model was used to study dispersal trajectories to and from the study area. Sampling was conducted between 31.07.14 and 04.04.16. A total of 13 families and 11 species were identified, expanding the total species list of the study area with six species and four families; $63 \%$ of fish larvae caught on the ARs were of reef associated species; abundance and species richness was higher on the ARs compared to samples taken at a distance from the ARs. First occurrence of the invasive muzzled blenny Omobranchus punctatus was registered. The hydrodynamic model provided insight on dispersal trajectories and connectivity. The results of this study can be used to better define guidelines for sustainable use of the ARs and the Currais archipelago, a Marine National Park since 2013.
\end{abstract}

KEYWORDS: fish larvae; reef fishes; light-trap; Currais; South Atlantic. 


\section{LIST OF FIGURES}

Figure 1 - A) Study area on the northern coast of Paraná State, south Brazil. Location of artificial reefs deployed by the REBIMAR project within dotted rectangle; B) Detail of Currais archipelago, ARs and control location at between 50 and $100 \mathrm{~m}$ from AR modules; C) Concrete blocks used to construct the ARs of the REBIMAR project; D) Currais archipelago on the Paraná coast...............................................................................

Figure 2 - Above: scooter with attached net. Below: scooter with net being steered by a

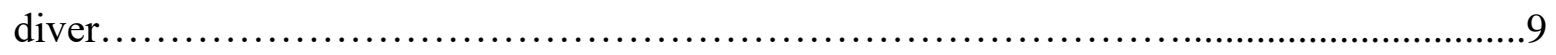

Figure 3 - Light-trap made from repurposed PET bottle. a) entrance; b) recipient; c) 350 $\mu \mathrm{m}$ mesh; d) battery within waterproof container; e) LED lightning system; f) cable; g) actual device; h) detail of waterproof container with batteries and LED light system; i) visual representation of the light-trap suspended in the water column between a bottom anchor and a mid-depth buoy 10

Figure 4 - Temperature of surface and bottom layers measured in the study area over the course of the study period, from July 2014 to April 2016.

Figure 5 - Salinity of surface and bottom layers measured in the study area over the course of the study period, from July 2014 to April 2016. 16

Figure 6 - Secchi measurements of water transparency from sampled months between July 2014 and April 2016 16

Figure 7 - a) Total abundance (in $\ln \left(\mathrm{n}_{\mathrm{x}}+1\right)$ ) of fish larvae sampled on AR and at a $>50 \mathrm{~m}$ distance from the ar. B) abundance of fish eggs sampled on vs. Off AR; c) total abundance (in $\ln \left(\mathrm{n}_{\mathrm{x}}+1\right)$ ) of fish larvae and eggs sampled on Currais.

Figure 8 - Proportions of larvae of different developmental stages in A) net/scooter samples and B) light-trap samples. 
Figure 9-a) Accumulation of taxa and individuals on ARs over the course of the sampling period; b) taxa and individual accumulation on Currais over the course of the sampling period. 20

Figure 10 - a) relative abundance of dominant families in samples; b) proportions of preferred habitat among sampled larvae; c) proportions of trophic categories among sampled

larvae.

Figure 11 - Dominant zooplankton group of each sampling location. Non-dominant groups of each location were categorized as "other". 23

Figure 12 - simulations showing incoming and outgoing trajectories; incoming trajectories (in shades of blue) illustrate the distance and trajectory traveled by a passive particle beginning 30 days prior to arriving at the sampling point on March 12 $2^{\text {th }}$; outgoing trajectories (in red, orange and yellow) illustrate the distance and trajectory traveled away from the sampling point in a time period of 30 days beginning March $12^{\text {th }}$ .26

Figure 13 - simulations showing incoming and outgoing trajectories; incoming trajectories (in shades of blue) illustrate the distance and trajectory traveled by a passive particle beginning 30 days prior to arriving at the sampling point on June $6^{\text {th }}$; outgoing trajectories (in red, orange and yellow) illustrate the distance and trajectory traveled away from the sampling point in a time period of 30 days beginning June $6^{\text {th }}$ 


\section{LIST OF TABLES}

Table 1 - Date, sampling point, sampling method and number of samples per sampling excursion. $\mathrm{LT}=$ Light-Trap; $\mathrm{AR}=$ Artificial Reef............................. 11

Table 2 - families and species of fish larvae from natural and artificial reef habitats in Paraná State. $\mathrm{PH}=$ preferential habitat: $\mathrm{REF}=$ reef associated; $\mathrm{PLG}=$ pelagic; $\mathrm{DEM}=$ demersal; $\mathrm{BPL}=$ benthopelagic. $\mathrm{TC}=$ trophic categories: $\mathrm{MIF}=$ mobile invertebrate feeders; $\mathrm{CAR}=$ generalist carnivores; $\mathrm{OMN}=$ omnivores; $\mathrm{HER}=$ herbivores; $\mathrm{PLA}=$ planktivores PIS = piscivores. YS = unidentified yolk-sac larvae; NI = not identified

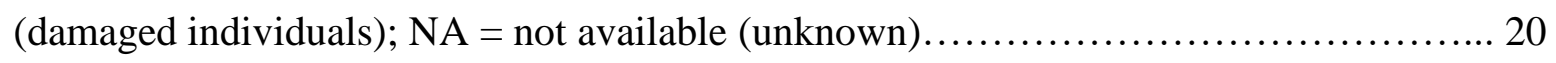

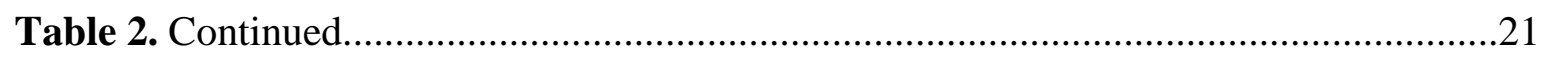




\section{INTRODUCTION}

Coastal marine ecosystems are some of the most vulnerable to degradation by anthropic impact; in addition to being centers of both commercial and recreational activities, approximately half of the world's population currently lives in coastal areas (HINRICHSEN, 1998; WOR, 2010). These ecosystems are both diverse and highly productive. Nursery grounds for fish and other marine organisms are frequent in coastal habitats such as mangroves, reefs and rocky shores; larvae and juveniles from these habitats later replenish offshore populations (NAGELKERKEN et al., 2015). Conflicts between commercial interests and ecological sustainability are reoccurring problems worldwide that threaten the integrity and future of vulnerable coastal ecosystems (WOR, 2010).

Over the last decades, mainly since the 1970`s, the inner shelf ecosystem of Paraná State in southern Brazil has been impacted by activities of commercial shrimp trawlers and associated by-catch, which amounts to 30-50\% of annual catch (BRANDINI, 2014). Physical destruction of benthic substrates caused by the use of large non-selective trawling nets has affected fish stocks with ecological and commercial importance as well as noncommercial species important for local small-scale fisheries. Destructive fishing methods and illegal fishing in no-take areas threaten the integrity of the inner shelf ecosystem as well as the socioeconomic sustainability of local small-scale fishing communities who are

forced to compete with both commercial and illegal vessels for limited resources (BORTONE et al., 2011; BRANDINI, 2014).

The Paraná coastline is one of the smallest in Brazil, extending only $98 \mathrm{~km}$. Destructive anthropic impacts on the inner shelf ecosystem are enhanced by the geomorphology of the bottom areas. Despite having a large meroplanktonic larval pool there are few habitats for epilithic microinvertebrates and other reef-associated organisms (BRANDINI and SILVA, 2011). The bottom is dominated by mud and sand, and natural consolidated habitats are rare, but the few that exist, Currais archipelago being the largest, are associated with high biomass and species diversity with both commercial and ecological importance (PINHEIRO, 2005; HACKRADT \& FÉLIX-HACKRADT, 2009). The Currais archipelago was established as a Marine Protected Area (MPA) in 2013 (BRASIL, 2013). 
Artificial reef (AR) installations have been used all over the world to recuperate marine biodiversity. The term "artificial reef", or sometimes also referred to as "artificial habitat", encompasses various definitions depending on factors such as their purpose and building materials; generally, the term is used when referring to submerged structures placed in the aquatic environment where these would not naturally occur, mimicking the characteristics of natural reef habitats (JENSEN, 1998; BAINE, 2001; JENSEN, 2002; CLAUDET \& PELLETIER, 2004; CRESSON et al., 2014).

Artificial reefs, like natural reef environments, are colonized by meroplanktonic larvae from the already existing larval pool in the water column. With time, the colonizing organisms set the foundation for the development of a biological community similar to that of natural rocky habitats nearby (BRANDINI \& SILVA, 2011; CRESSON et al., 2014). The establishment of ARs is associated with different objectives, such as: (i) increasing the heterogeneity of the environment, offering shelter for local fauna (CLAUDET \& PELLETIER, 2004); (ii) colonization of sessile epilithic macroinvertebrates that provides food for other organisms; (iii) increasing the complexity of the habitat for new settlers (BRANDINI \& SILVA, 2011); (iv) as protection against destructive fishing methods (JENSEN, 2002; BRANDINI, 2014); (v) recreational activities, like scuba diving; (vi) for scientific purposes, such as increasing knowledge about settling processes (CLAUDET \& PELLETIER, 2004; BRANDINI \& SILVA, 2011; BORTONE et al., 2011) and (vii) hard substrate habitat restoration (BORTONE et al., 2011).

Studies have documented increased biological production after deployment of ARs, but the role of ARs in production of biomass is still subject to debate, often referred to as the "production vs. attraction controversy" (BOHNSACK, 1982; POLOVINA \& SAKAI, 1989; CARR \& HIXTON, 1997; PICKERING \& WHITMARSH, 1997; CRESSON et al., 2014; OSENBERG et al., 2002; BRICKHILL et al., 2005). Artificial reefs have a great potential for aggregating and attracting fish (BROCHIER et al., 2015) and increased fish biomass on ARs are frequently observed (OSENBERG et al., 2002; CRESSON et al., 2014). However, if artificial reefs only attract fish from surrounding habitats, then their presence could cause overfishing by increasing the proportion of the population removed by unit of effort, which could in turn lead to further decline in the fish stock (BOHNSACK, 
1982; OSENBERG et al., 2002; CRESSON et al., 2014). The production hypothesis on the other hand states that ARs can effectively recuperate biological communities of rocky habitats by the recruitment of new individuals through increased food availability and shelter (CRESSON et al., 2014). To resolve the attraction/production controversy studies from the last decade has focused on trophic ecology, specifically the use of stable isotope analyses (BRICKHILL et al. 2005; KANG et al., 2008; DAIGLE et al. 2013).

Since the late 1990`s, ARs have been established within the inner shelf of Paraná State, most recently by the REBIMAR project of the MarBrasil Association (SILVA et al., 1997; BRANDINI \& SILVA 2011; BRANDINI, 2014). The reefs were deployed as a mean of protection against destructive trawling activities and with the objective of recuperating marine biodiversity associated with rocky reef habitats (BRANDINI \& SILVA 2011; BRANDINI, 2014). CARR and HIXTON (1997) stressed the importance of comparing ARs to natural reefs; the ARs on the Paraná coast are located geographically close to the islands of Currais and the adult fish community is similar in both habitats (PINHEIRO, 2005; HACKRADT \& FÉLIX-HACKRADT, 2009). To validate the use and construction of ARs in Brazil, it is essential to prove that the reefs not only attract marine organisms, but that they are in fact evolving into larval recruitment sites that favor production of new biomass.

The reef-associated ichthyofauna of Brazil is highly diverse and species rich; species richness diminishes gradually towards the south and southeast regions of the country, but despite having lower species richness, the south and southeast regions are home to several endemic species (FLOETER and GASPARINI, 2000; FLOETER et al. 2001). Historically, the reef-associated ichthyofauna of the Western South Atlantic has been poorly studied compared to its northern counterpart, only in the mid-to-late 1990's did the research efforts along the extensive Brazilian coast increase (FLOETER et al. 2001). The knowledge gaps in relation to Brazilian reef ichthyofauna are still many, even more so in the case of larval fish fauna. Previous research concerning reef-associated ichthyofauna of the Currais archipelago and ARs on the coast of Paraná State have focused on adult fish (PINHEIRO, 2005; HACKRADT \& FÉLIX-HACKRADT, 2009; DAROS et al., 2012). The studies of reef ichthyofauna in Paraná have characterized the adult fish populations of 
the Currais reef habitats as well as the populations of the ARs, but the icthyoplanktonic community of these locations have not yet been studied.

The ecology and natural history of fish in their larval stages differs greatly from those of adult fish. Fish larvae are morphologically and ecologically very different from adults; adult fish and larvae exhibit different behavior, often inhabit different habitats and exhibit very different feeding habits (LEIS \& CARSON-EWART, 2000; RICHARDS, 2006). Morphologically, early stage larvae may not share any characteristics of their adult counterparts, but as they develop into juveniles they gradually gain adult characteristics (LALLI \& PARSONS, 1997; RICHARDS, 2006; LEIS \& CARSON-EWART, 2000). Because of these significant differences, it is important to acquire knowledge of the early life history of the larval fish community, only this way can the current state of fish populations in the study area be fully understood.

During the egg stage and pelagic larval stages, which may last from a few days to several weeks, fish larvae are subject to dispersal by ocean currents (LEIS \& CARSONEWART, 2000; LEIS et al. 2011). As the fish larvae develop, however, they are increasingly capable of swimming in an oriented and deliberate way, positioning themselves in the water column and actively following olfactory and auditory cues to find food and shelter or to avoid predators (LEIS et al. 2011). Fish larvae also exhibit lightdependent behaviour; variations in light conditions influence larval behaviour and positioning within a school, and are also associated with net-avoidance and vertical migration (BLAXTER \& HUNTER, 1982).

Because of the many factors influencing larval dispersal, models attempting to accurately predict dispersal need to be increasingly complex; simpler hydrodynamic models of ocean circulation can, however, be useful when studying dispersal of fish eggs and larvae in very early developmental stages. One such model is the The Princeton Ocean Model (POM), originally developed by BLUMBERG \& MELLOR (1987), the model has been adapted for the Southeast Brazilian coast by HARARI and CAMARGO (2003). 


\subsection{Purpose and Objectives of this Research}

Artificial reefs have only recently been subject of scientific study in Brazil and the ichthyoplankton community associated with the reef structures deployed in Paraná, as well as that of Currais, is still practically unknown. The hypotheses of this study are: (1) The abundance of fish larvae and eggs will be greater at the artificial reefs than in adjacent, noreef areas; (2) Samples will contain fish eggs and recently hatched fish larvae if reproduction of fish is occurring in the area, and; (3) The larval fish assemblage of the artificial reefs will be similar in species composition and ecological diversity to the larval fish assemblage of the adjacent Currais archipelago. Additionally, this study aims to characterize the larval fish community and discuss possible larval dispersal trajectories and ecological connectivity within the study area.

\section{MATERIALS AND METHODS}

\subsection{Study site}

The study area is located on the inner shelf of Paraná State, southern Brazil (Fig. 1A), which comprise part of the South Brazil Bight (SBB) between $23^{\circ} \mathrm{S}$ and $28.5^{\circ} \mathrm{S}$ (CASTRO et al. 2006). The inner shelf is primarily influenced by two different water masses: Costal Water (CW) and South Atlantic Central Water (SACW). CW has low salinity $(<35)$ because of coastal runoff and warm temperatures $\left(>20^{\circ} \mathrm{C}\right)$, while $\mathrm{SACW}$ is colder $\left(<20^{\circ} \mathrm{C}\right)$, has higher salinity $(<36)$ and is rich in nutrients (BRANDINI, 1990; CASTRO et al., 2006). The seasonal hydrographic patterns are well defined; SACW intrudes in lower layers during summer (December-March) when northeastern winds dominate and surface water is transported offshore by Ekman transport. Upper layers $(<20$ m) are dominated by $\mathrm{CW}$, creating a mid-depth thermocline. During winter (JuneSeptember) SACW does not penetrate towards the coast, leaving the inner shelf with CW only (CASTRO FILHO, 1987; CERDA and CASTRO, 2014).

It is rare, however, that SACW intrudes all the way to the Currais archipelago. The sampled areas are mostly influenced by sediments of terrestrial origin because of runoff 
from the large estuarine bays of Paranaguá and Guaratuba (BRANDINI, 1990; CASTRO et al. 2006; BRANDINI \& SILVA, 2011; BRANDINI, 2014), during winter the region also receives terrigenous sediments from the La Plata river and the estuary of Lagoa dos Patos (BRANDINI, 1990). The bottom geomorphology is overall characterized by a lack of hard bottom substrates. Bottom substrates consists of sand, silt and clay; the percentage of silt and clay between the 5 and $15 \mathrm{~m}$ isobaths range from $10 \%$ to $40 \%$ due to large amounts of fine particles in the continental runoff from the adjacent, large estuarine complex (BRANDINI and SILVA, 2011).

Paraná State is located close to the southern limit of the Brazilian Province, a zoogeographical province for Western Atlantic fish fauna. The Brazilian province stretches from the Amazon Delta to Santa Catarina State, where rocky reefs are no longer influenced by the Brazil Current (FLOETER and GASPARINI, 2000).

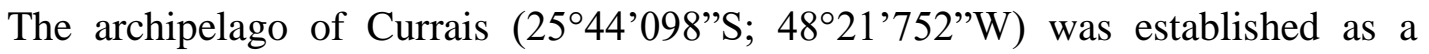
Marine National Park (PARNA Marinho das ilhas dos Currais) in 2013 because of its ecological importance, covering an area of 1.359,70 hectares (BRASIL, 2013). The National Park is fully protected, meaning that only indirect use of the parks resources is permitted; indirect use is defined as "one that does not involve consumption, collection, damage or destruction of natural resources" (BRASIL, 2000). The archipelago, located approximately seven nautical miles from the shore, is composed of three islands surrounded by rocky reefs. The south and southeastern parts of the islands are affected by strong wind and wave action, while the northern parts are more protected with calmer waters. Apart from Currais, natural rocky reef habitats in the area are limited to a few bottom reefs,

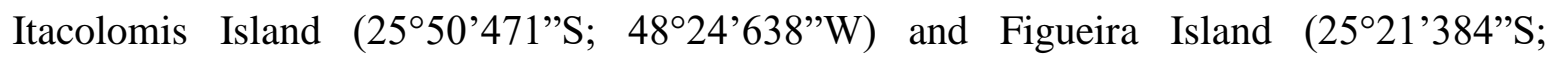
$48^{\circ} 02^{\prime} 103$ 'W). 


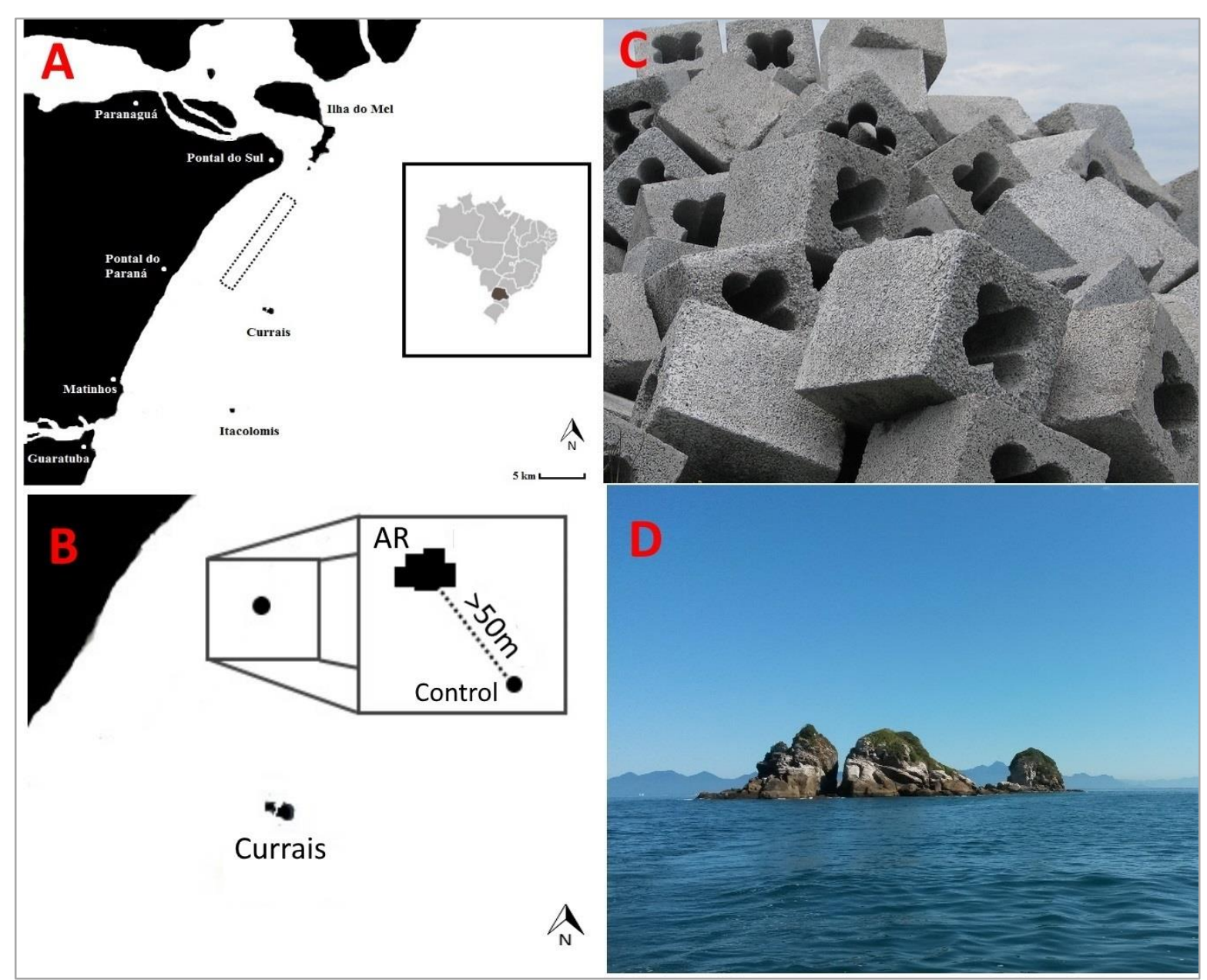

Figure 1 - A) Study area on the northern coast of Paraná State, south Brazil. Location of artificial reefs deployed by the REBIMAR project within dotted rectangle; B) Detail of Currais archipelago, ARs and control location at between 50 and 100 m from AR modules; C) Concrete blocks used to construct the ARs of the REBIMAR project; D) Currais archipelago on the Paraná coast.

The first artificial reefs in the region were implanted as part of the Marine Artificial Reefs program (RAM) beginning in 1997, when reef modules were deployed between Currais and Itacolomis Island. Between 2011 and 2012 ten new ARs were deployed in a line perpendicular to the coast by the Recuperation of Marine Biodiversity Program (REBIMAR) of the MarBrasil Association (Fig. 1A.).

The ARs deployed as part of the REBIMAR project are composed of concrete blocks specifically designed for larval recruitment (Fig. 1C). The concrete blocks are hollow with a "four leaf clover" shape to increase surface area, they have an uneven surface to facilitate fixation of epilithic organisms and are enriched with silica to recreate the $\mathrm{pH}$ 
value of natural rocky reefs. The concrete blocks were tied together with wire before deployment, thus creating a non-uniform pile with cavities of different sizes and shapes between the blocks in addition to the space within each block.

\subsection{Sampling methodology}

Samples of fish larvae were collected in the water column directly above AR structures and at $>50 \mathrm{~m}$ from the ARs as a control (Fig. 1B). An additional sampling point was located on the natural rocky reef on the north side of the Currais archipelago (Fig. 1D). All sampling points were located within the $10-18 \mathrm{~m}$ isobaths. Two methodologies were used for sampling fish larvae and fish eggs; 1) light-traps and; 2) towed net attached to an underwater scooter adapted from BELDADE et al. (2006) and BORGES et al. (2007).

The scooter (Seadoo GTS 30M) was manually controlled by a diver (Fig. 2) at a speed of approximately 1.5 knots. The plankton net had a mesh size of $350 \mu \mathrm{m}, 0.30 \mathrm{~m}$ mouth diameter and a mouth diameter/net length ratio of $1: 3$ (total net length $=1.5 \mathrm{~m}$ ). This ratio was chosen for maneuverability reasons. A Flowmeter (LUNUS 2030R) was attached to the mouth of the net to obtain the volume of water filtered in each tow. Annotation of the flowmeter numbers was done by an accompanying diver at the start and end of the tow. Each tow had duration of five minutes after which the diver would close the net and ascend to the surface. When towing close to the reefs, a distance of approximately $0.50 \mathrm{~m}$ from the substrate was maintained. When sampling at the control location an accompanying diver would secure a line at the AR while the diver maneuvering the scooter would remove himself as far away from the reef as the line would permit (at a minimum of $50 \mathrm{~m}$ from the reef), before proceeding with a 5-minute tow. Once at surface the content of the sampling cup was stored in labeled containers and preserved in buffered formalin (4\%) before transport to the laboratory for further analysis. 


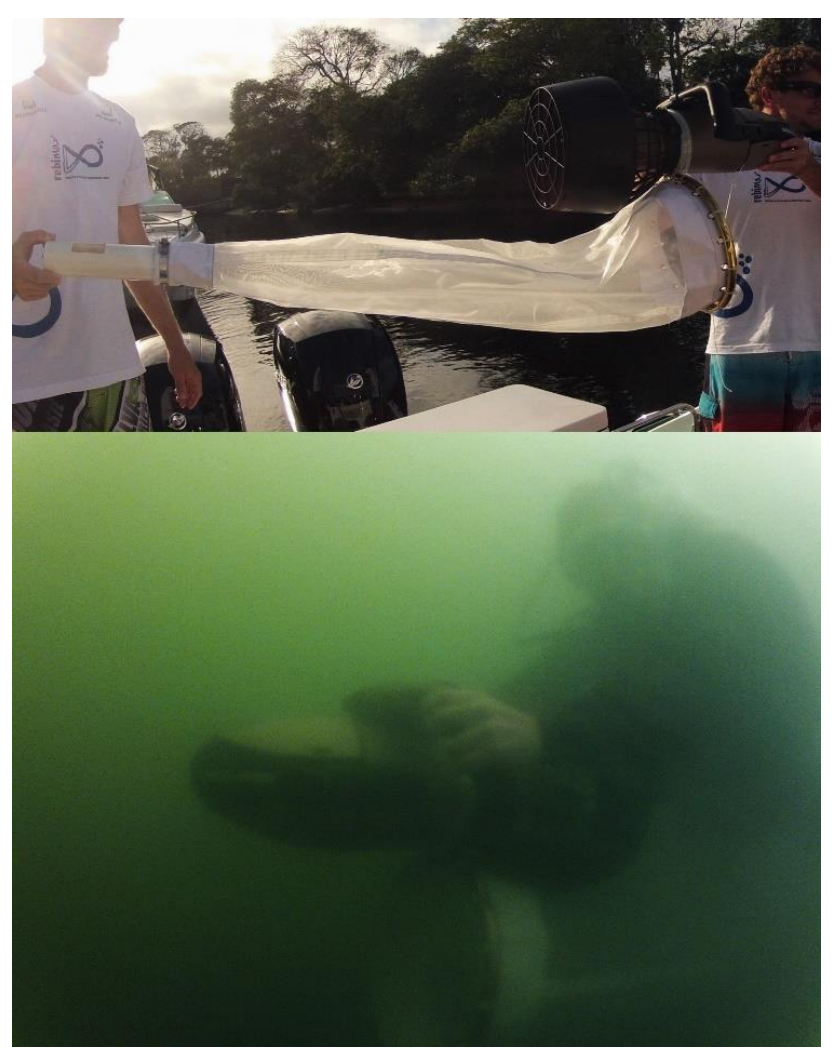

Figure 2 - Above: Scooter with attached net. Below: Scooter with net being steered by a diver.

Light traps used in this study were made from repurposed PET containers (20 L), with a LED light system and batteries within a waterproof cylinder in the center (Fig. 3). Eight openings were cut symmetrically around the PET container (Fig. 3a); eight LED lights were then positioned within the waterproof cylinder so that each light pointed directly at an opening in the trap. The LED lights were controlled with a reed switch, an electrical switch which is operated magnetically. A magnet was placed on the outside of the waterproof cylinder, at the position of the reed switch located on the inside; before deployment of the light-trap the magnet was removed, activating the LED lights. A PVC pipe coated with a $350 \mu \mathrm{m}$ mesh was used to retain collected material (Fig. $3 \mathrm{~b}$ and $3 \mathrm{c}$ ). The light-traps were held in suspension in the water column between a bottom anchor and a mid-depth buoy; a separate cable connected the anchor to a surface buoy (Fig. 3i). The middepth buoy provided enough buoyancy for the light-trap to remain in a vertical position. 


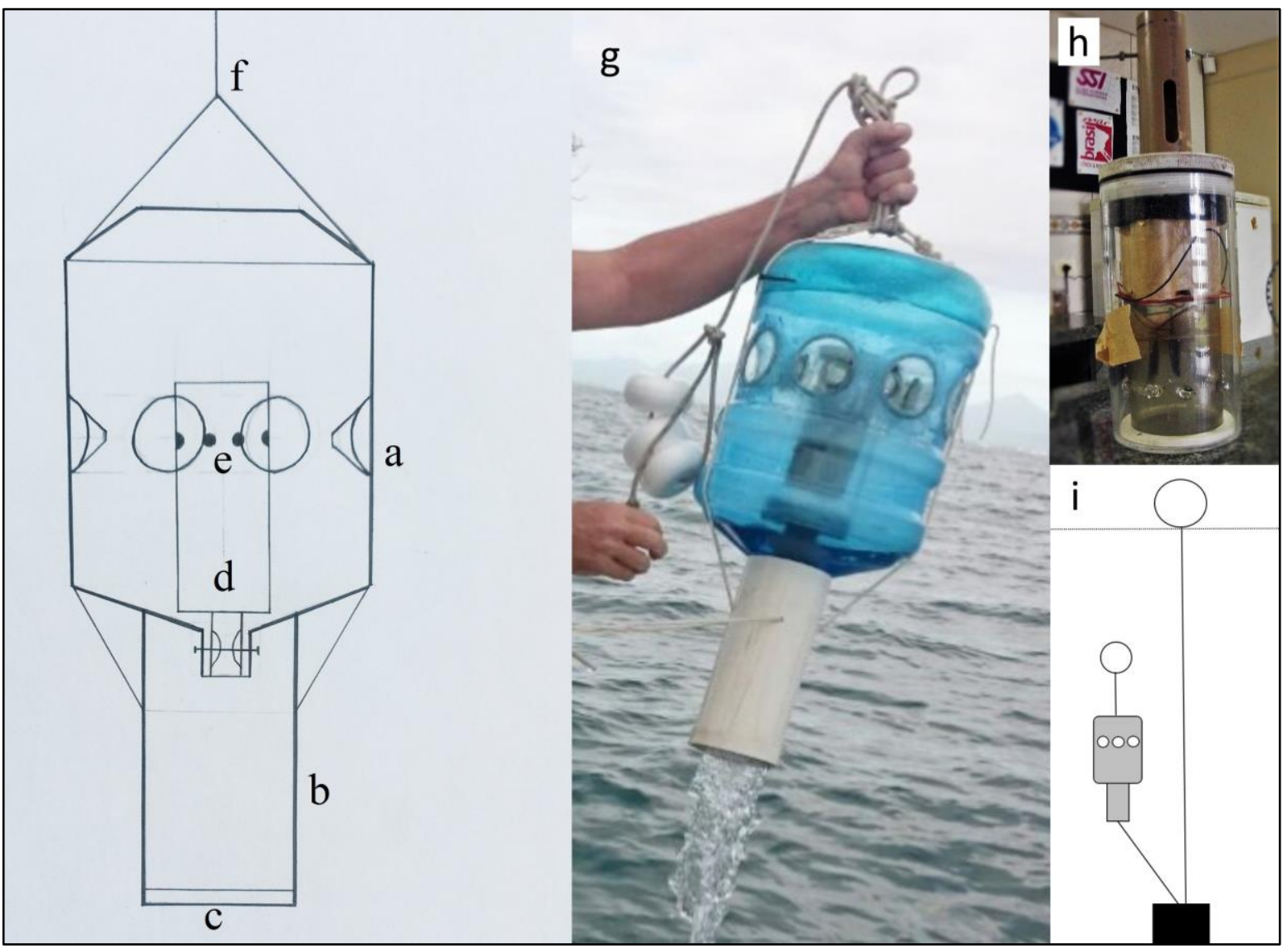

Figure 3 - Light-trap made from repurposed PET bottle. a) entrance; b) recipient; c) $350 \mu \mathrm{m}$ mesh; d) battery within waterproof container; e) LED lightning system; f) cable; g) actual device; h) detail of waterproof container with batteries and LED light system; i) visual representation of the lighttrap suspended in the water column between a bottom anchor and a mid-depth buoy.

The light-traps were deployed in the afternoon and recovered as early as possible the following day. One light-trap was placed directly on the AR while another would be placed at between 50 and $100 \mathrm{~m}$ from the AR. Collected material contained in the sampling cup was stored in labeled containers and preserved in buffered formalin (4\%) before transport to the laboratory for further analysis.

In total, 11 sampling excursions were conducted from 31.07.14 to 04.04.16, over the course of which 37 individual samples were collected; 15 on the AR, 15 control samples and 7 samples from Currais (Table 1). Abiotic data was collected once during each sampling excursion; water temperature and salinity were measured with a multiparameter 
probe; water visibility was measured with a secchi disk. Because of the proximity between sampling locations, abiotic data was only measured at one location per sampling excursion.

Table 1 - Date, sampling point, sampling method and number of samples per sampling excursion. $\mathrm{LT}=$ Light-Trap; AR = Artificial Reef.

\begin{tabular}{ccccccc}
\hline Date & \multicolumn{2}{c}{ Control } & \multicolumn{2}{c}{ AR } & \multicolumn{2}{c}{ Currais } \\
& LT & Scooter & LT & Scooter & LT & Scooter \\
\hline 31.07 .14 & & 2 & & 2 & & \\
02.08 .14 & 1 & 1 & 1 & 1 & & \\
07.01 .15 & & 1 & & 1 & & \\
14.01 .15 & 3 & 3 & 3 & 3 & & \\
02.02 .15 & 1 & & 1 & & 1 & \\
12.03 .15 & 1 & & 1 & & 1 & \\
03.06 .15 & & & & & & 1 \\
06.06 .15 & 1 & & 1 & & 1 & 2 \\
12.12 .15 & 1 & & 1 & & & \\
21.01 .16 & 1 & & 1 & & & 1 \\
04.04 .16 & & 2 & & 2 & & \\
\hline
\end{tabular}

Accessibility to the sampling locations was limited by difficult weather conditions, large waves and strong winds made navigating by boat difficult and sometimes impossible for months at a time. Environmental conditions in the study area are affected by the proximity to estuaries of the Paranaguá and Guaratuba bays, coastal runoff from heavy rainfalls and frequent meteorological cold fronts. Heavy rainfall usually occurs in the warmer months from October to March, but also follows cold fronts in winter months. Originally, sampling was planned on several ARs in the area in addition to samples from Currais, but because sampling proved difficult due to environmental conditions the sampling effort was concentrated on one of the reefs in addition to the control and Currais. Poor water visibility limited use of the scooter and net, for this reason sampling could on occasion only be done with the light-traps. 


\subsection{Laboratory proceedings}

In the laboratory fish larvae and eggs were separated from zooplankton under a stereomicroscope and conserved in alcohol (70\%) in new, labeled bottles. Zooplankton was taxonomically separated by order and counted for abundance data to identify differences in zooplankton composition between sampling points. Fish eggs were separated and counted. Fish larvae were photographed and the following measurements were registered using the software ImageJ (http://imagej.nih.gov/ij/); Body Length (corresponding to notochord length in preflexion larvae and Standard Length (SL) in postflexion larvae), Pre-Anal Length (PL) and Head Length (HL). All larvae were identified to the lowest possible taxonomic level according to MATSUURA (1977); WHITEHEAD et al. (1988); LEIS \& CARSON-EWART (2000), and RICHARDS (2006).

The developmental stage of each fish larvae was determined per the definitions of KENDALL et al. (1984), which is based on the degree of flexion of the notochord and divides the larval stages of fish into three main stages; preflexion, flexion and postflexion. A larva is considered preflexion from the end of yolk-sac stage until the beginning of notochord flexion. The flexion stage lasts until the degree of notochord flexion reaches a position of approximately $45^{\circ}$ from the axis of the notochord. Postflexion larvae with early signs of juvenile characteristics were classified as transformation larvae.

Abundance data $\left(\mathrm{N}_{\mathrm{x}}\right)$ was transformed to natural logarithm $\left(\ln \left(\mathrm{N}_{\mathrm{x}}+1\right)\right)$ for better visualization of the data in graph form. Accumulation curves were made for Currais and the ARs to graphically compare the cumulative number of new taxa and individuals over the course of the sampling period. The graphs were made dual with two Y-axes and a shared $\mathrm{X}$-axis to show both accumulated number of taxa and accumulated number of individuals.

Habitat and trophic categories were defined according to literature (LEIS \& CARSON-EWART, 2000; FLOETER et al., 2004; RICHARDS, 2006; Fishbase.org). Preferred Habitat $(\mathrm{PH})$ was attributed to each species within the following categories: Rocky Reef (RR), species associated with rocky reef environments; Demersal (DEM), lives and feeds on organisms closely associated with bottom substrates; Pelagic (PLG), occurs 
between 0 and $200 \mathrm{~m}$ and does not feed on benthic organisms and; Benthopelagic (BPL), lives and feeds on or close to bottom substrates as well as in the water column.

Trophic categories (TC) for each species was defined as either: Herbivores (HER); Sessile Invertebrate Feeders (FIS); Motile Invertebrate Feeders (MIF), Piscivores (PIS), Omnivores (OMN), Generalist Carnivores (CAR) or Planktivorous (PLA). Fish larvae are Planktivorous, meaning that they mainly feed on zooplankton, trophic categories attributed to fish species in this study consequently refers to the most common diet associated with their adult feeding habits.

The lists of taxa presented by PINHEIRO (2005), HACKRADT \& FÉLIXHACKRADT (2009) and DAROS et al. (2012) were compared to the larval fish taxa collected in this study, species lists from all these works were collected and combined in to one table to obtain a more complete list of species.

\subsection{Data analysis}

Water volume $\left(\mathrm{m}^{3}\right)$ sampled by the net of the underwater scooter was calculated by first calculating the total distance $(\mathrm{m})$ traveled by the scooter using equation 1 (obtained from manufacturer of the flowmeter):

$$
\text { Distance }=\frac{(\text { difference } \times 26.873)}{999999}
$$

where "difference" refers to the number of rotations of the flowmeter at the end of the trawl subtracted by the starting number. The volume of water sampled can then be calculated by equation 2 (obtained from manufacturer of the flowmeter);

$$
\text { Volume }=3.14 \times\left(\frac{\text { diameter }}{4}\right) \times \text { distance }
$$

where "diameter" refers to the diameter of the mouth of the net used, in this case $0.30 \mathrm{~m}$. 


\subsection{Hydrodynamic model}

The Princeton Ocean Model (POM) is a three-dimensional numerical model of oceanic circulation, originally developed by BLUMBERG \& MELLOR (1987) it is now of public domain in its basic version. A hydrodynamic model based on the POM, adapted by HARARI and CAMARGO (2003), was used to study probable dispersal trajectories of planktonic fish eggs and very early stage larvae to and from the ARs and Currais archipelago. The model covers the SBB area and has previously been implemented for the entire coastal area of São Paulo State (HARARI et al., 2006). Ocean circulation is simulated using data sets from Simple Ocean Data Assimilation version 2.2.4 (SODA2.2.4), global inverse tide model (TPXO7.1) and NCEP Reanalysis I for atmospheric data. The single grid used in this study reaches from coordinates -50.5751 27.3186 (southwest corner) to $-41.3387-22.9960$ (northeast corner), has 22 vertical sigma levels and a horizontal resolution of $1 \mathrm{~km}$.

Two dates (12.03.15 and 06.06.15) were chosen for the simulations; these were chosen for having highest abundance of fish larvae during the sampling period of this study. Data from years 2000 - 2010 was used to create two sets of eight figures, one set for each date. The figures are subdivided according to year: $2000-2002 ; 2003-2005 ; 2006-$ 2008; 2009 - 2010, and separated between surface layers and bottom layers. Simulations were made with a time period of 30 days prior to - and following the chosen date. Dispersal trajectories were color coordinated: shades of blue representing trajectories arriving at the sampling point on the chosen date (incoming trajectories) and red/orange/yellow representing trajectories leaving the sampling point on the chosen date (outgoing trajectories). The resulting figures were overlaid maps derived from Google Earth ${ }^{\mathrm{TM}}$ to better visualize the trajectories in relation to the coastline and sampling points. 


\section{RESULTS}

\subsection{Environmental variability}

Surface water temperature in the sampling area varied between $21.1^{\circ} \mathrm{C}$ (measured in July, 2014) and $28.6^{\circ} \mathrm{C}$ (measured in January, 2015) (Fig. 4). Bottom water temperature varied between $20^{\circ} \mathrm{C}$ (measured in July, 2014) and $27.6^{\circ} \mathrm{C}$ (measured in January 2015). There was some thermal stratification in the summer months but temperature variation measured between surface and bottom layers never exceeded $1.34^{\circ} \mathrm{C}$. Surface salinity in the sampling area varied between 33.15 (measured in March, 2015) and 35.5 (measured in both January and February, 2015) (Fig. 5). The greatest haline stratification occurred in March 2015. Secchi measurements (Fig. 6) varied between $3.1 \mathrm{~m}$ (summer) and $7 \mathrm{~m}$ (winter). An El Niño event occurred simultaneously with study period, beginning in late 2014 and continuing throughout 2015 and the beginning of 2016.

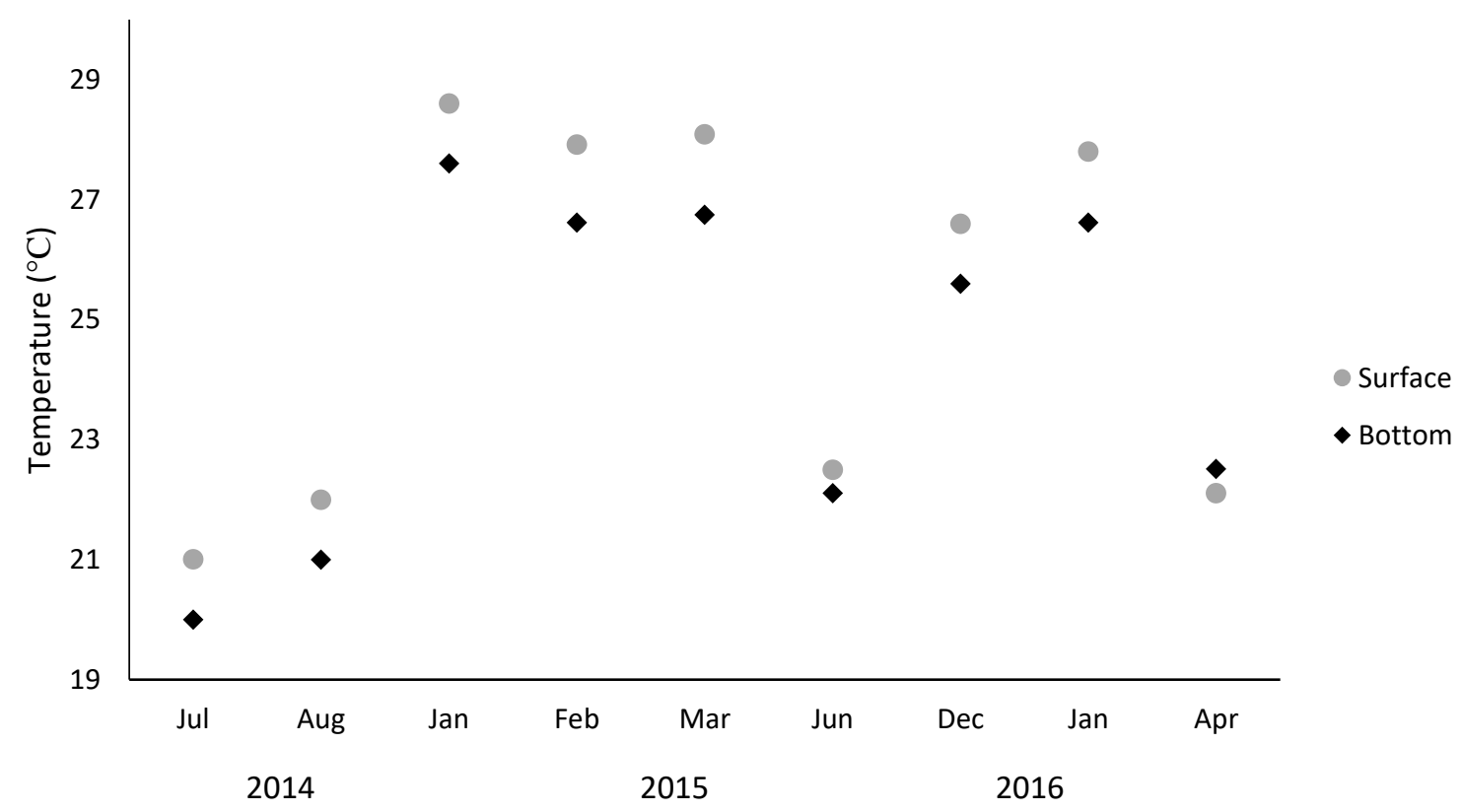

Figure 4 - Temperature of surface and bottom layers measured in the study area over the course of the study period, from July 2014 to April 2016. 


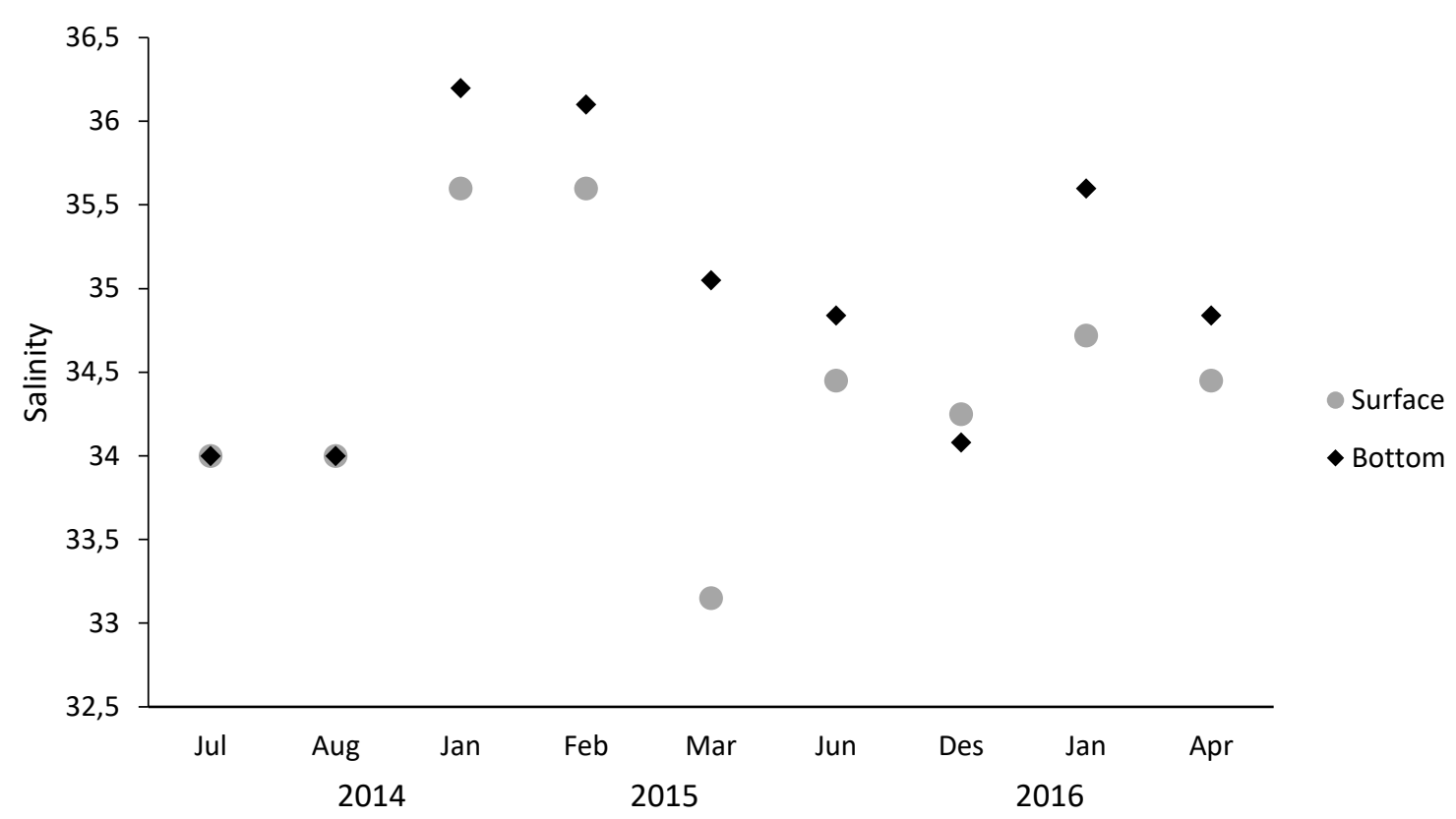

Figure 5-Salinity of surface and bottom layers measured in the study area over the course of the study period, from July 2014 to April 2016.

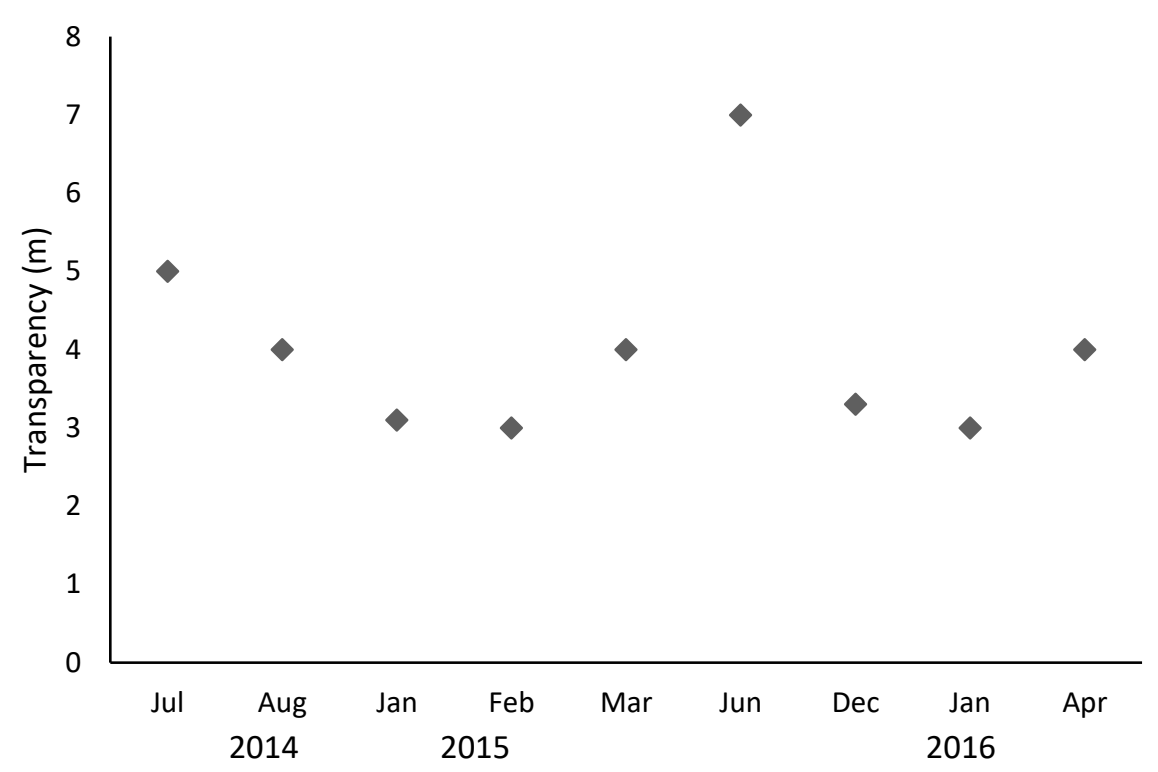

Figure 6 - Secchi measurements of water transparency from sampled months between July 2014 and April 2016. 


\subsection{Biological data}

A total of 277 fish larvae and 272 fish eggs were collected; 141 fish larvae and 80 fish eggs were collected in AR samples, while 25 fish larvae and 42 fish eggs were collected in control samples. In Currais, a total of 111 fish larvae and 149 fish eggs were collected. Highest abundance of fish larvae occurred in March for AR samples (Fig. 8A) and in June for control samples (Fig. 8B). Highest fish larvae abundance in Currais samples occurred in June (Fig. 8C). Highest abundance of fish eggs occurred in January for all sampling locations.

Total abundance of larvae was $84 \%$ higher on the AR compared to the control samples. Total abundance of fish eggs was $47.5 \%$ higher in AR samples compared to control samples. In February (2015), December (2016), January (2016) and April (2016) fish larvae were not present at all in control samples. Fish eggs were completely absent in control samples from December (2015), January (2016) and April (2016). In August, February and March only light-traps were deployed in Currais due to insufficient water visibility for scooter/net samples.

Calculations showed that the scooter sampled an average of $6.05 \mathrm{~m}^{3}$ of water during each 5-minute sampling trawl. Average light-trap sampling period was 20 hours. Accumulation curves for the ARs (Fig. 9A) illustrate how the number of collected individuals was low in the initial samples, then increased exponentially after the seventh sampling excursion. The accumulation of new species increased during the whole sampling period and never reached a stable plateau. Differently from the AR, the accumulation of individuals in samples from Currais (Fig. 9B) had a more stable increase from the beginning. Accumulation of new species increased rapidly from the start but never reached a stable plateau. Fewer sampling excursions were made to Currais, but the average number of individuals collected per sample, as well as the number of species sampled, was higher compared to the ARs.

Fish larvae belonging to all developmental stages were found on all sampling locations, but proportions of larvae of different developmental stages present in samples varied according to sampling method (Fig. 7A and 7B). Preflexion stage larvae accounted 
for $56.6 \%$ of larvae collected in scooter/net samples, $33 \%$ were yolk-sac larvae, $6.6 \%$ were in flexion stage and $3.3 \%$ were postflexion larvae. Fish eggs were only present in scooter/net samples, except for one single egg present in a light-trap sample from January (2016). No yolk-sac larvae were collected in light-trap samples. In light-trap samples, postflexion stage larvae accounted for $95 \%$, while $3 \%$ were in flexion stage, $1 \%$ was in transformation stage and $1 \%$ was preflexion stage larvae.

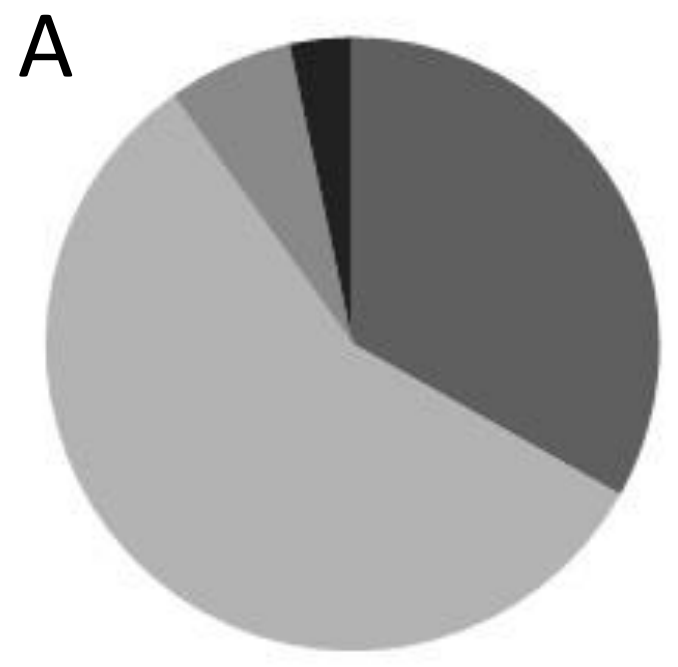

Yolk-sac Preflexion

Flexion Postflexion

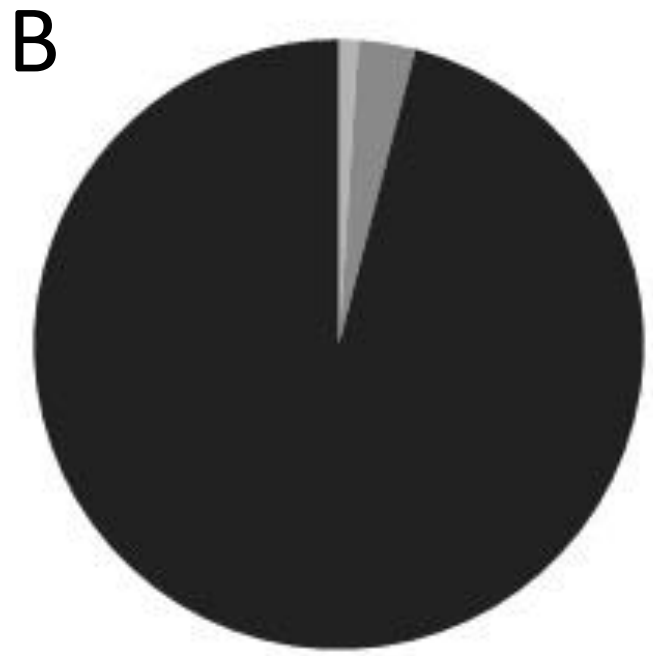

Yolk-sac Preflexion

- Flexion Postflexion

Figure 7 - Proportions of larvae of different developmental stages in A) net/scooter samples and B) light-trap samples. 

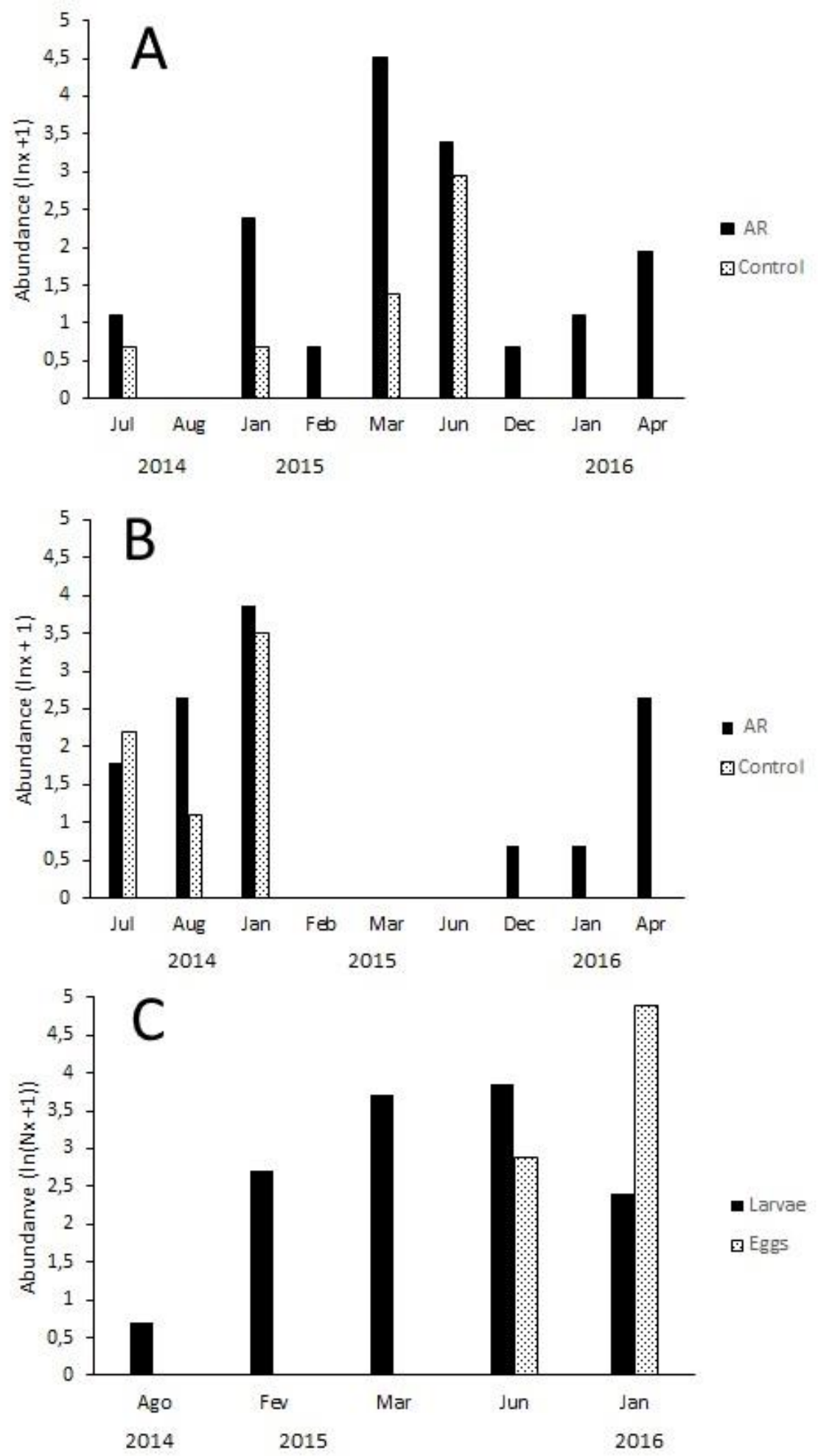

Figure $8-A$ ) Total abundance (in $\ln \left(N_{X}+1\right)$ ) of fish larvae sampled on AR and at control location. B) Abundance of fish eggs sampled on ARs compared to the control; C) Total abundance (in $\ln \left(\mathrm{N}_{\mathrm{X}}+1\right)$ ) of fish larvae and eggs sampled on Currais. 


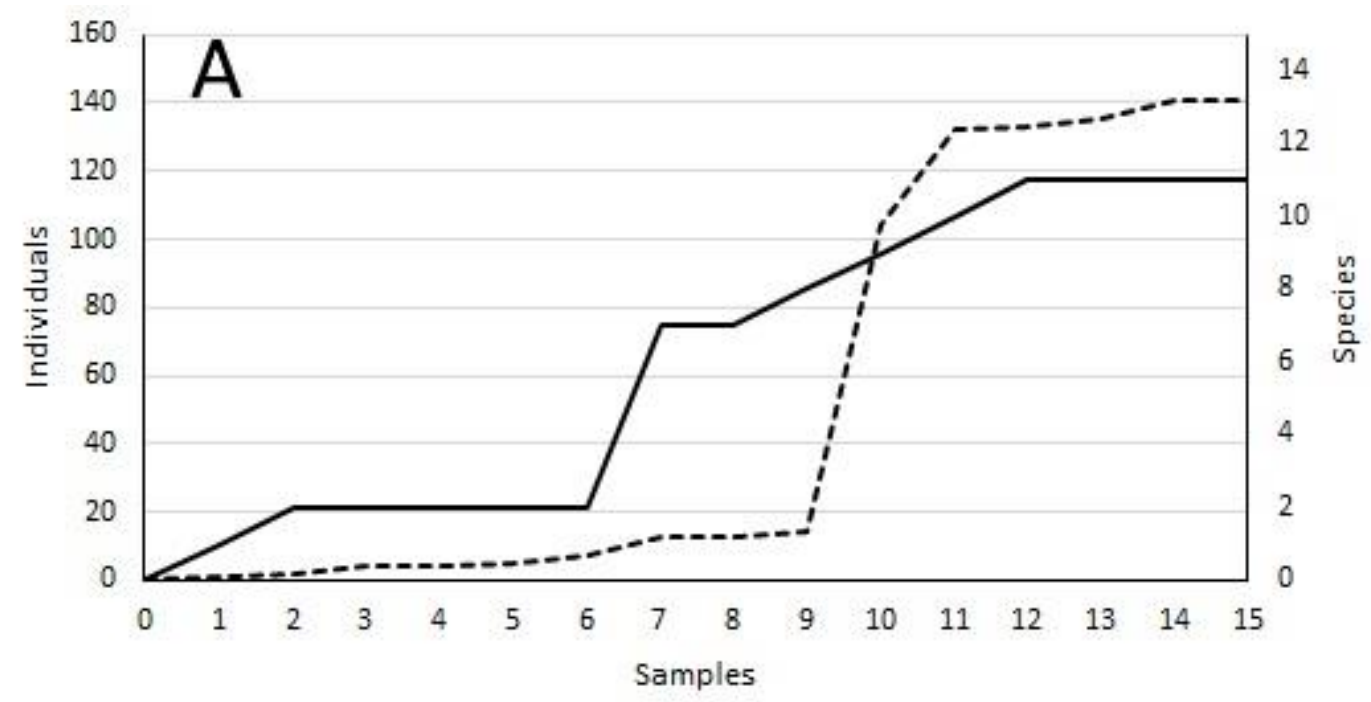

-.-.. Ind ividual accumulation - Species accumulation

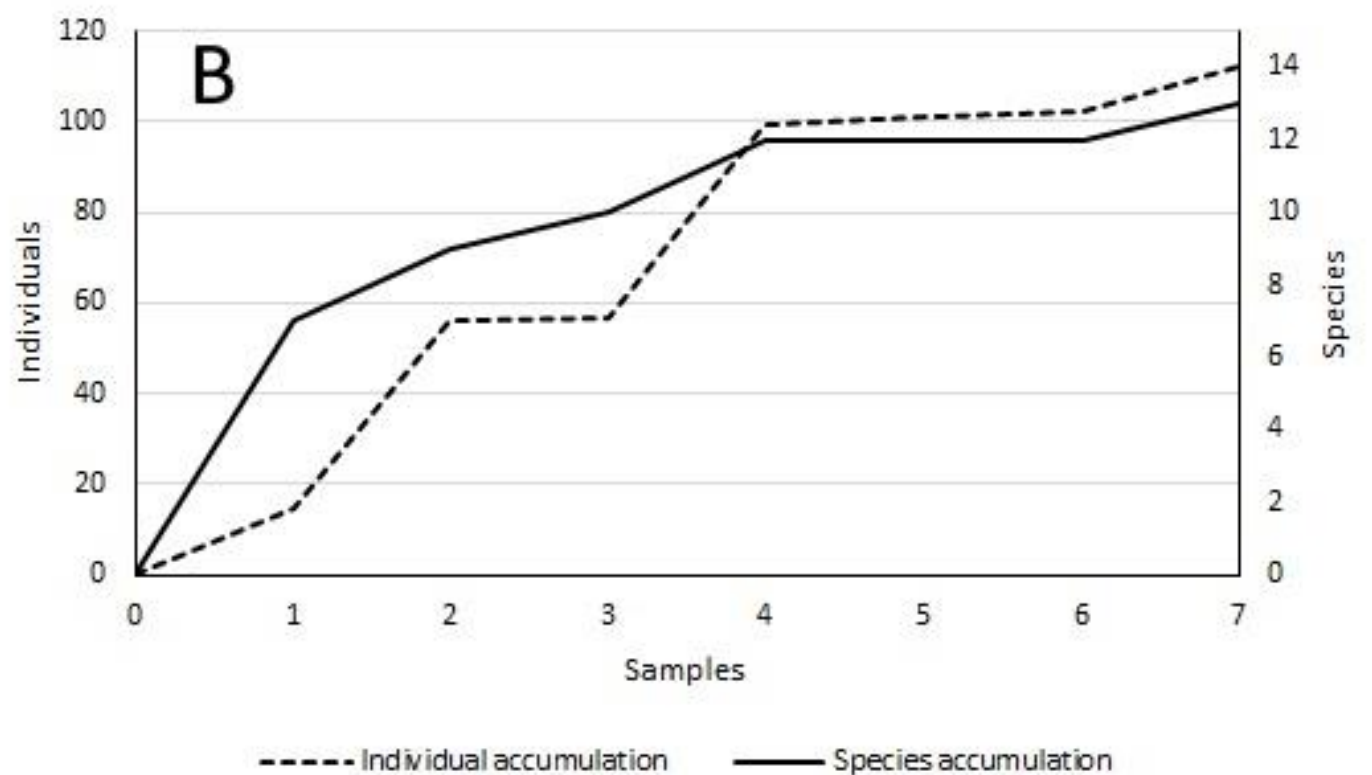

Figure 9-A) Taxa and individual accumulation on ARs over the course of the sampling period;

B) Taxa and individual accumulation on Currais over the course of the sampling period. 
A total of 11 different species were identified (Table 2), individuals belonging to these species accounted for $86 \%$ of all collected larvae, $8.7 \%$ of fish larvae were only identified to family level. The remaining fish larvae were either not identifiable because they were recently hatched yolk-sac larvae lacking identifiable characteristics (4\%), or they were left unidentified because of significant structural damage (1.4\%). Out of the 272 fish eggs collected, seven were elliptical and identified as eggs of the family Engraulidae.

The most abundant families collected on the AR were: Carangidae (64\%), Engraulidae (22\%) and Clupeidae (3.5\%) (Fig. 10A); the most abundant species were Caranx ruber (Carangidae) and Engraulis anchoita (Engraulidae). The most abundant families collected at control location were: Engraulidae (83\%) and Carangidae (8.7\%); the most occurring species were Engraulis anchoita and Chloroscombrus chrysurus (Carangidae). The most abundant families in samples from Currais were: Haemulidae (33\%), Clupeidae (31\%) and Engraulidae (10\%); the most occurring species were: Haemulon aurolineatum (Haemulidae), Harengula jaguana (Clupeidae) and Engraulis anchoita.

The species Engraulis anchoita, Chloroscombrus chrysurus, Harengula jaguana and Omobranchus punctatus (Blenniidae) were found in samples from both AR and Currais. The specie Caranx ruber was only found in AR samples, while Trichiurus lepturus (Trichiurinae) was found in both AR and in control samples, but not in samples from Currais. The species Coryphopterus spp. (Gobiidae), Dactyloscopidae sp. (Dactyloscopidae), Diapterus rhombeus (Gerreridae), Bardiella ronchus (Sciaenidae) and Synodus foetens (Synodontidae) were only found in samples from Currais. Sciaenidae sp. and Labrisomidae sp. were found both in AR samples and Currais samples but because they were in very early developmental stages the identification was uncertain and the individuals may or may not have been of the same species.

Two individuals of the invasive muzzled blenny Omobranchus punctatus were collected in this study. One individual was captured in a light-trap sample from the AR on February $2^{\text {nd }} 2015$; the larva was in postflexion stage and had a SL of $18.76 \mathrm{~mm}$. The second $O$. punctatus larvae was captured in a light-trap sample from Currais on March $12^{\text {th }}$ 2015; the larva was in postflexion stage and had a SL of $9.81 \mathrm{~mm}$. 
Table 2 - Families and species of fish larvae from natural and artificial reef habitats in Paraná state. $\mathrm{PH}=$ Preferential Habitat: $\mathrm{REF}=$ Reef associated; $\mathrm{PLG}=$ Pelagic; DEM $=$ Demersal; $\mathrm{BPL}=$ Benthopelagic. $\mathrm{TC}=$ Trophic Categories: $\mathrm{MIF}=$ Motile Invertebrate Feeders; $\mathrm{CAR}=$ Generalist Carnivores; OMN = Omnivores; HER = Herbivores; PLA = Planktivores; PIS = Piscivores. YS = Unidentified Yolk-Sac larvae; NI = Not Identified (damaged individuals); NA = Not Available (unknown).

\begin{tabular}{|c|c|c|c|c|c|}
\hline Family/Species & PH & TC & Control & AR & Currais \\
\hline \multicolumn{6}{|l|}{ Blenniidae } \\
\hline Omobranchus punctatus (Valenciennes, 1836) & BPL & MIF & & 1 & 1 \\
\hline \multicolumn{6}{|l|}{ Carangidae } \\
\hline Caranx (Carangoides) ruber (Berry, 1959) & REF & PIS & & 84 & \\
\hline Chloroscombrus chrysurus (Linnaeus, 1766) & PLG & PLA & 2 & 7 & 1 \\
\hline \multicolumn{6}{|l|}{ Clupeidae } \\
\hline Sardinella brasiliensis (Steindachner, 1879) & PLG & PLA & & & 3 \\
\hline Harengula jaguana (Poey, 1865) & REF & OMN & & 2 & 31 \\
\hline Clupeidae sp. & NA & NA & 1 & 2 & \\
\hline \multicolumn{6}{|l|}{ Dactyloscopidae } \\
\hline Dactyloscopidae sp. & DEM & MIF & & & 6 \\
\hline \multicolumn{6}{|l|}{ Engraulidae } \\
\hline Engraulis anchoita (Hubbs \& Marini, 1935) & PLG & PLA & 18 & 29 & 11 \\
\hline Engraulidae spp. & PLG & PLA & 2 & 3 & \\
\hline \multicolumn{6}{|l|}{ Gerreridae } \\
\hline Diapterus rhombeus (Cuvier, 1829) & DEM & OMN & & & 1 \\
\hline \multicolumn{6}{|l|}{ Gobiidae } \\
\hline Coryphopterus sp. & REF & HER & & & 6 \\
\hline \multicolumn{6}{|l|}{ Haemulidae } \\
\hline Haemulon aurolineatum (Cuvier, 1830) & REF & MIF & & & 37 \\
\hline \multicolumn{6}{|l|}{ Labrisomidae } \\
\hline Labrisomidae sp. & REF & MIF & & & 5 \\
\hline \multicolumn{6}{|l|}{ Sciaenidae } \\
\hline Sciaenidae sp.1 & NA & NA & 1 & 1 & \\
\hline Bairdiella ronchus (Cuvier, 1830) & DEM & MIF & & & 2 \\
\hline
\end{tabular}


Table 2 - Continued

\begin{tabular}{|c|c|c|c|c|c|}
\hline Family/Species & PH & TC & Control & AR & Currais \\
\hline \multicolumn{6}{|l|}{ Synodontidae } \\
\hline Synodus foetens (Linnaeus, 1766) & PLG & CAR & & & 1 \\
\hline \multicolumn{6}{|l|}{ Trichiurinae } \\
\hline Trichiurus lepturus (Linnaeus, 1758) & BPL & PIS & 1 & 1 & \\
\hline YS 1 & NA & NA & & 1 & \\
\hline YS 2 & NA & NA & & 1 & \\
\hline YS 3 & NA & NA & & 2 & 1 \\
\hline YS 4 & NA & NA & & 1 & \\
\hline YS 5 & NA & NA & & & 2 \\
\hline YS 6 & NA & NA & & 2 & \\
\hline NI 1 & NA & NA & & 1 & \\
\hline $\mathrm{NI} 2$ & NA & NA & & 1 & \\
\hline $\mathrm{NI} 3$ & NA & NA & & 2 & 2 \\
\hline
\end{tabular}

Most fish larvae collected on the AR were reef-associated species (61\%), followed by larvae of pelagic species (28\%); in control samples, most fish larvae (96\%) were of pelagic species while the remaining larvae (4\%) were of benthopelagic species (Fig. 10B). Most fish larvae collected in Currais were reef-associated (72\%), followed by pelagic $(14.5 \%)$ and demersal species $(8 \%)$. As for the trophic structure, there was a predominance of planktivores in the samples overall (Fig. 10C). Planktivorous species were dominant in control samples (95.6\%), second most abundant in AR samples (26\%) and present, but not dominant in Currais samples (13\%). In AR samples piscivores were most abundant (60\%), but planktivores, omnivores, and motile invertebrate feeders were also present. Motile invertebrate feeders were most abundant in Currais (45.5\%). Samples from Currais had the greatest variation including all described trophic categories except sessile invertebrate feeders. 


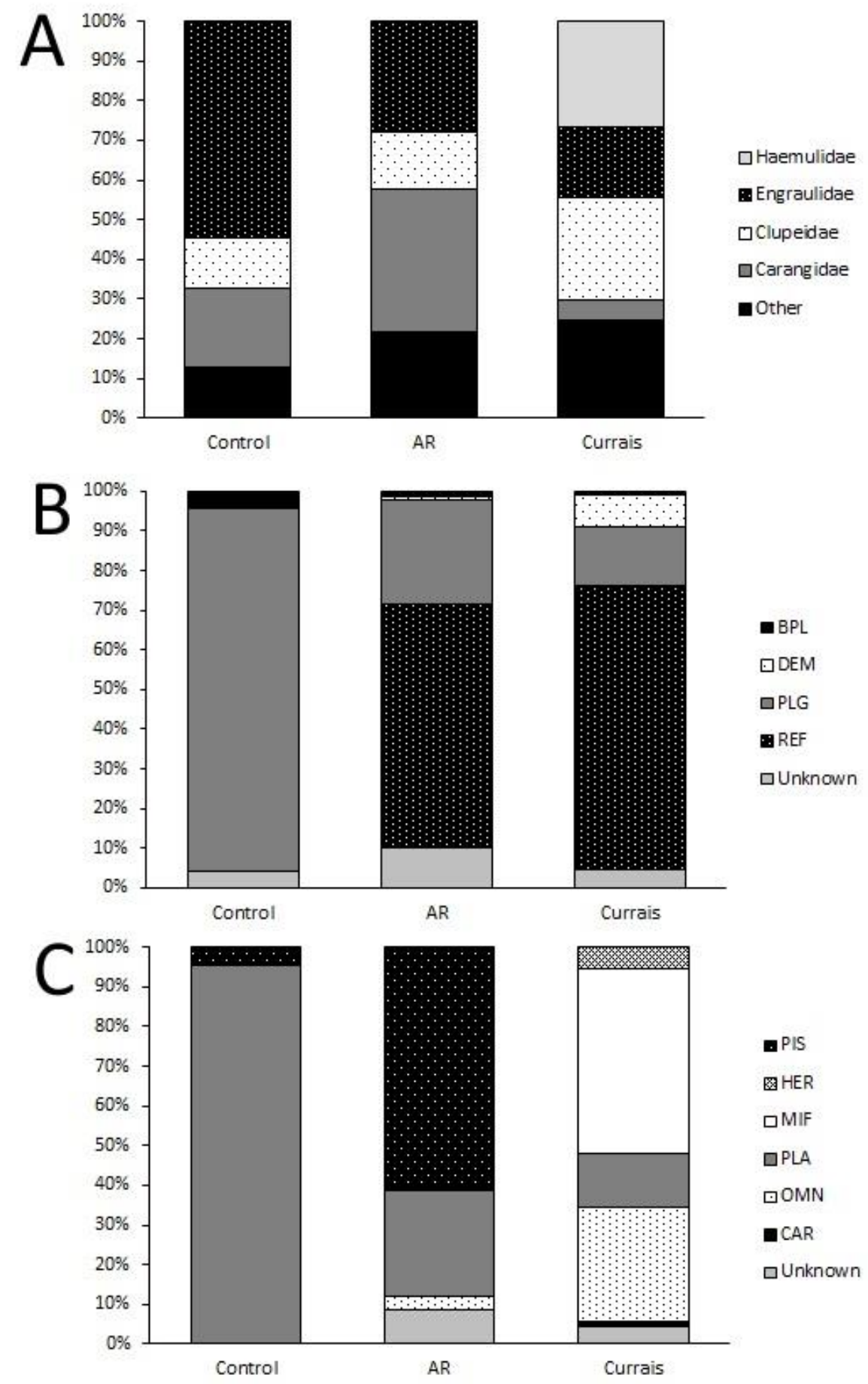

Figure 10 - A) Relative abundance of dominant families collected; B) Proportions of preferred habitat among sampled larvae; C) Proportions of trophic categories among sampled larvae. $\mathrm{PH}=$ Preferential Habitat: REF $=$ Reef associated; PLG = Pelagic; DEM = Demersal; $\mathrm{BPL}=$ Benthopelagic. $\mathrm{TC}=$ Trophic Categories: $\mathrm{MIF}=$ Motile Invertebrate Feeders; $\mathrm{CAR}=$ Generalist Carnivores; OMN = Omnivores; HER = Herbivores; PLA = Planktivores PIS = Piscivores. 
The referenced studies of adult fish fauna of the ARs and Currais (DAROS et al. 2012; HACKRADT \& FÉLIX-HACKRADT, 2009 and PINHEIRO, 2005) have listed a total of 74 species present on the ARs and 80 species present in Currais (Appendix A). A total of 60 species were present on both the ARs and Currais. Eight species were found exclusively on the ARs: Balistes capriscus (Balistidae), Hypsoblennius invemar (Blenniidae), Echeneis naucrates (Echeneidae), Pomatomus saltatrix (Pomatomidae), Rachycentron canadum (Pomatomidae), Rhinobatus percellens (Rhinobatidae), Archosargus probatocephalus (Sparidae) and Diapterus rhombeus (Gerreidae); 17 species were found exclusively in Currais.

Dominant taxa of zooplankton captured in both light-trap and scooter/net samples varied among the three sampling areas (Fig. 11). In Currais, the dominant group was the order Cumacea followed by the orders Mysida and Decapoda. On the AR Cladocera was the overall dominant taxa, followed by Copepoda, Gastropoda and Polychaeta. In control samples the dominant zooplankton taxa was Copepoda, followed by Cladocera, Polychaeta and Gastropoda. Zooplankton abundance was relatively stable in all scooter/net samples during the study period. Zooplankton abundance in light-trap samples fluctuated more and was overall lower than in scooter/net samples.

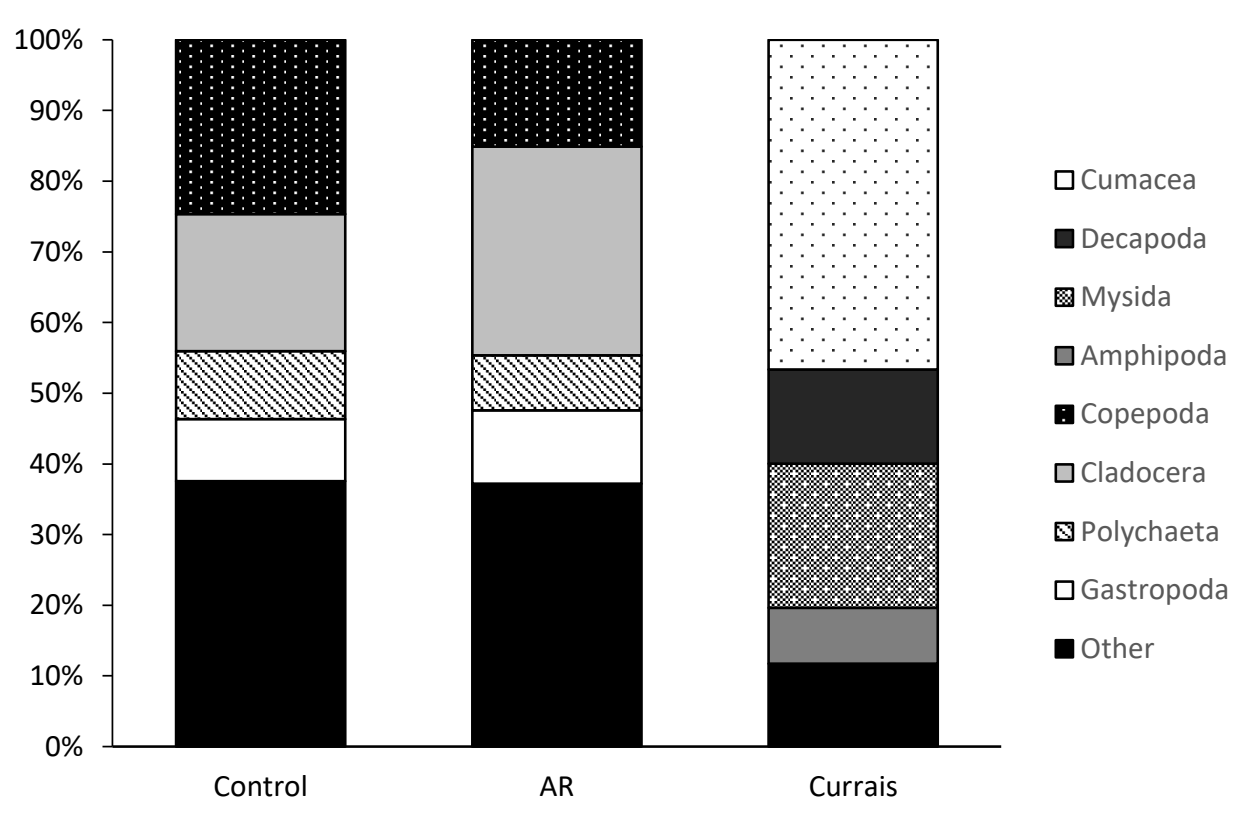

Figure 11 - Dominant zooplankton groups of each sampling location. Non-dominant groups of each location were categorized as "other". 


\subsection{Hydrodynamic model}

Simulations from the hydrodynamic model showed trajectories from the northeast point of the mouth of Paranaguá Bay towards Currais and continuing trajectories from Currais towards Guaratuba Bay. Some similarities and some differences were observed between March (Fig. 10) and June simulations (Fig. 11), and between surface and bottom layers.

Bottom currents are slower than surface currents and simulations from both summer (2006, 2007, 2010) and winter (2000, 2006, 2008, 2010) showed considerable shorter trajectories during the 30-day time period in bottom layers compared to surface layers. Most incoming trajectories follow the coastline, but bottom simulations from 2000, 2003 (March) and 2001, 2003, 2007 (June) showed how incoming trajectories arrive from off shore regions rather than following the coastline.

Surface simulations also showed variations; most of the simulated trajectories follow the coastline but in 2000 and 2010 (March); 2006, 2007 and 2010 (June), trajectories proceed with a series of directional changes and minor vortices. Outgoing dispersal trajectories mostly follow the coastline towards the southwest, but surface trajectories sometimes proceed with alternate paths away from the coast (June: 2002, 2007, 2008), towards the coast (March: 2000, 2002, 2006 and 2007; June: 2000, 2002, 2006) or southeast away from the coast (June: 2001, 2007 and 2008). In a timeframe of 30 days, according to this model, pelagic ichthyoplankton present in the water column of the ARs and Currais could be lead as far as Guaratuba Bay. The majority of all simulated dispersal trajectories leading away from the sampling area followed a direct trajectory towards

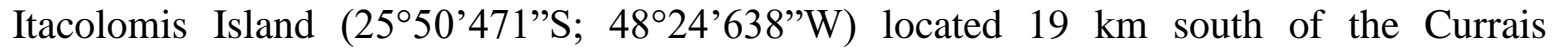
archipelago. 


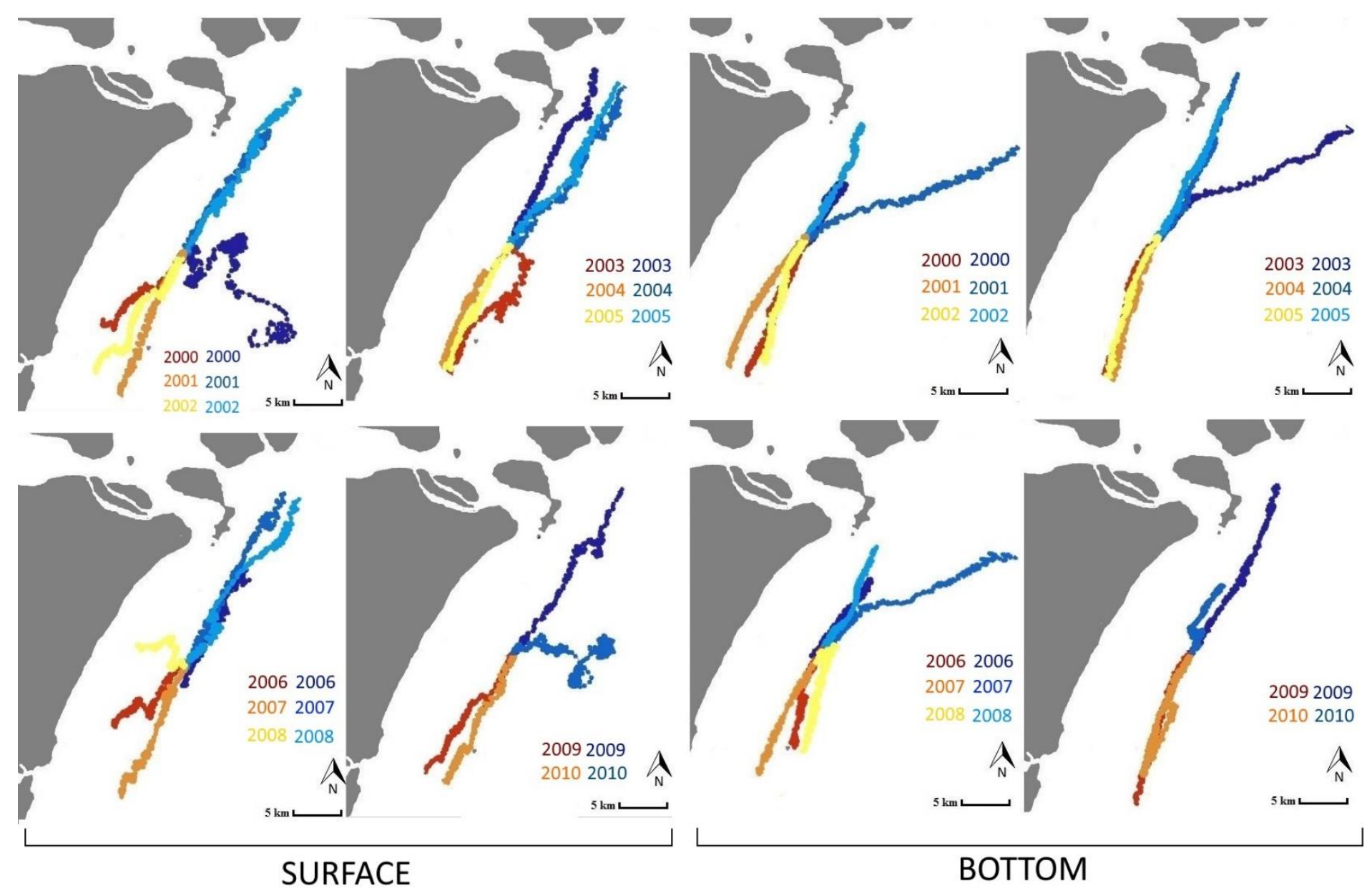

Figure 12 - Incoming trajectories (in shades of blue) illustrate the distance and trajectory traveled by a passive particle beginning 30 days prior to arriving at the sampling point on March $12^{\text {th }}$; outgoing trajectories (in red, orange and yellow) illustrate the distance and trajectory traveled away from the sampling point in a time period of 30 days beginning March $12^{\text {th }}$. 


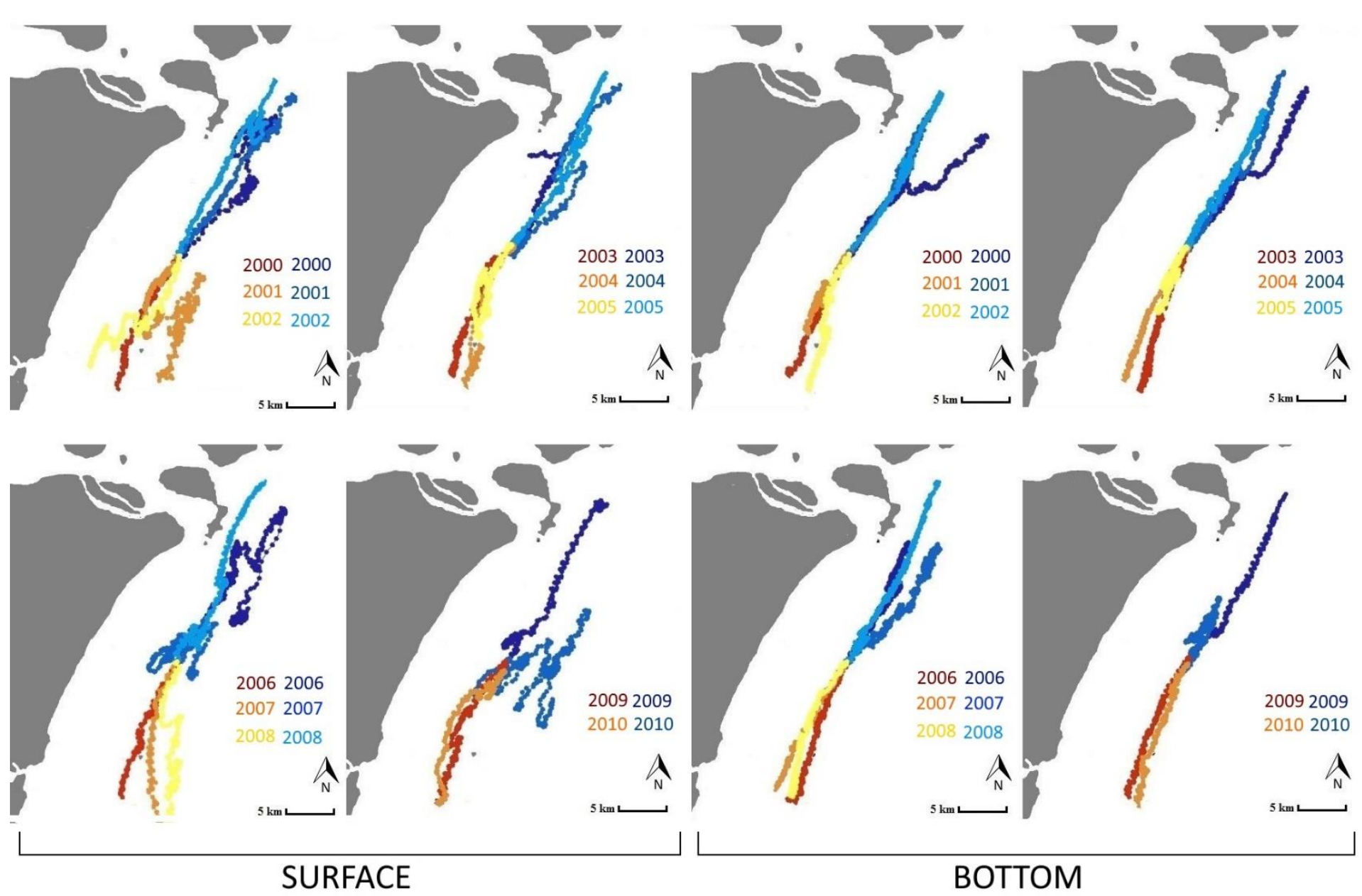

Figure 13 - Incoming trajectories (in shades of blue) illustrate the distance and trajectory traveled by a passive particle beginning 30 days prior to arriving at the sampling point on June $6^{\text {th }}$; outgoing trajectories (in red, orange and yellow) illustrate the distance and trajectory traveled away from the sampling point in a time period of 30 days beginning June $6^{\text {th }}$. 


\section{DISCUSSION}

An El Niño event occurred during the study period. El Niño events are known to cause rainfall and streamflow anomalies in the Southwest Atlantic (SEVEROV et al., 2014), but more meteorological and oceanographic data would be needed to determine if the El Niño event did in fact influence condition in the study area. Although water temperature and salinity variations were within the normal range, strong winds, frequent cold fronts and poor water visibility in the study area lead to difficulties with navigation and deployment of research equipment; because of this, sampling could not be conducted as regularly as initially planned.

Both sampling methods chosen for this study have previously been used successfully in other studies. The use of light-traps in structurally complex environments has previously been described by DOHERTY (1987); BROGAN (1994); HERNANDEZ \& SHAW (2003) and LINDQUIST \& SHAW (2005) among others. DOHERTY (1987) used light-traps successfully and described them as an inexpensive tool with great potential. BROGAN (1994) pointed out that even in optimal conditions many taxa or age classes are never attracted to light-traps and that even among the attracted larvae, behavioural differences in reaction to the traps vary and not all attracted organisms will actually enter the trap. HERNANDEZ and SHAW (2003) compared light-traps to towed nets and described them as useful for capturing unique taxa not collected by nets. LINDQUIST \& SHAW (2005) showed that fish larvae catches were negatively affected by increased current speed and high turbidity. These previous studies all suggested that to sample the larval assembly in its entirety, light-traps should be used in combination with other sampling methods when possible, such as towed nets. The use of towed nets attached to an underwater scooter has previously been described and successfully used by BELDADE et al. (2006) and BORGES et al. (2007). BORGES et al. (2007) showed how the scooter and towed net technique enabled sampling at very close proximity to the bottom and complex structures such as rocky reefs or artificial reef modules. 
Both methods used in this study are selective; net avoidance by more developed larvae causes the scooter/net method to be selective towards fish eggs and fish larvae in early developmental stages. Whether a fish larvae enters the light-traps or not, and by what mechanism, is dependent on both biotic and abiotic factors (BROGAN, 1994). For fish larvae to enter the trap purposely they must display photopositive behavior and possess sufficient swimming ability, however, not all captured larvae enter the trap on purpose; the transport and mixing of water can cause fish eggs and any fish larvae present in vicinity of the light-trap to enter.

The accumulations curves (Fig. 7) showed that accumulation of new taxa increased throughout the study period and did not at any point reach a stable plateau. It is likely that continued sampling efforts would result in continued accumulation of new taxa. Continued sampling efforts with a greater sampling size would likely reveal more about differences in spatial variation of species in the study area; with the current data set, samples showed greater temporal variation than spatial.

The ARs are surrounded by extensive flat unconsolidated bottom substrate of mud and sand, but their location is geographically close to the Currais archipelago which is rich in natural rocky reef habitat on all sides of its three islands. HACKRADT \& FELIXHACKRADT (2009) compared the ichthyofauna community of Currais and ARs and found that the majority $(60.6 \%)$ of species found in Currais were characteristic for rocky reef environments while the AR had a lower but still relatively high occurrence of rocky reef species (39.34\%). Samples revealed that, compared to Currais, the ARs had a greater number of pelagic species (26.81\%) and demersal species associated with sandy unconsolidated substrates (19.67\%). Results concluded that ichthyofauna of the ARs are still greatly influenced by surrounding environments with its high abundance of demersal and pelagic species.

Reef-associated, demersal, pelagic and benthopelagic species were all captured on the ARs. The abundance of pelagic clupeiform species is indicative of the attraction-effect of the ARs on its surroundings. Aside from a variety of habitat preferences among the species collected, samples also showed a variety of trophic categories; generalist carnivores were most abundant, but mobile invertebrate feeders and planktivores species were all 
present. Fish larvae samples collected in Currais showed greater variety in all aspects, in addition to containing a superior number of species and families overall. These results are consistent with the patterns observed in studies of adult fish in the study area (HACKRADT \& FELIX-HACKRADT, 2009). The presence of larvae of early developmental stages, from eggs to transformation larvae, suggests the possibility of reproduction on or close to the ARs. This would indicate that the AR ecosystem has succeeded in creating a favorable habitat for reef-associated fish species.

There was a difference in the composition of major zooplankton groups between Currais and the other sampling points. Samples from the ARs and control were practically identical in terms of composition of dominant taxa; abundance of zooplankton, however, was higher in AR samples compared to control samples. Dominant zooplankton taxa from Currais were very rare or less frequently observed in AR samples. Pelagic holoplanktonic taxa such as copepods and cladocerans were dominant groups on and around the ARs, while cumaceans and mysids dominated samples from Currais. The difference between zooplankton samples from the ARs and Currais, as well as the strong similarity between samples from ARs and control, illustrate how the reefs are still under strong influence from the surrounding environment. Although zooplankton samples had a similar composition of dominant species, abundance of all groups were higher in AR samples, suggesting that the reefs not only attract fish from surrounding waters, but also pelagic invertebrates.

The invasive muzzled blenny Omobranchus punctatus is a costal and brackish water species that live in cryptic benthic habitats. The cryptic nature of the species causes it to seek refuge in small holes, such as ballast-intake holes found on ship hulls. In Brazil, $O$. punctatus has been found in both ballast water and ships' biofouling and has been shown to thrive in both natural and artificial environments (GERHARDINGER et al., 2006; LASSOALCALÁ et al., 2011; CONTENTE et al., 2015). The specie is native to the Indo-Pacific; it was first recorded in the Atlantic Ocean in 1931 on the coast of Trinidad. In Brazil, the species has primarily been recorded in the northeast; occurrences of the species in Paraná's neighboring states includes: one adult individual of the species captured in a tide pool in São Sebastião Channel, São Paulo State (CONTENTE et al., 2015) and a reproducing population in Babitonga Bay, Santa Catarina State (COSTA et al., 2011). There are still 
several gaps in the records of its distribution, especially in the southeast and south Brazil. This study reports the first record of $O$. punctatus in Paraná State.

In southeast and south Brazil O. punctatus has primarily been found in and around harbors, generally located within bays. The individuals collected in this study were found geographically close to the mouth of Paranaguá Bay, which holds one of the largest harbors in Brazil. It is likely that the species could be present within the bay where if may establish a viable population the same way the species has already accomplished in Babitonga Bay, Santa Catarina (COSTA et al., 2011). The ARs and natural rocky reef habitats of Currais attract several species present in the water masses as they provide food and refuge, because of this, monitoring species present on the ARs could provide insight on the potential dispersal of invasive species in the area.

Six species and four families collected in this study were not listed in previous studies of adult fish from the ARs and Currais (Appendix A). The family Engraulidae was not listed in these studies, while both larvae and eggs of the family were collected in the present study. The presence of species and families that do not seem to frequent the ARs or Currais as adults suggests that the rocky reefs of the islands as well as the artificial habitats may provide protection and feeding grounds for fish larvae during their most vulnerable life-stages before they move on to different habitats as adults.

Of the eight species that were found exclusively on the ARs in the previous studies of adults, one (Diapterus rhombeus) was also found in the present study; the larva was found in a sample from Currais. Diapterus rhombeus is a demersal species, the remaining seven species were reef-associated (B. capriscus, E. naucrates, $R$. canadum and A. probatocephalus), demersal (H. invemar and $R$. percellens) and pelagic (P. saltatrix). Continued sampling efforts would be required to determine if these species are also present on the ARs in their larval stages.

The hydrodynamic simulation was created using data from a 10-year period (2000 2010); although not from the actual sampling period of this study the simulations were still considered relevant based on the long timescale of collected data used as reference for the model and consistency of the overall results. Nearly all fish species have a pelagic larval 
state. The duration of the pelagic larval stage varies over orders of magnitude between species and families, the same is true for dispersal distances (SALE, 2009; LEIS and CARSON - EWART, 2000; LALLI \& PARSONS, 1997). Historically, larval fish have been considered passive organisms, however research has shown that larval fish have a more active role (LEIS et al., 2011); by orienting themselves horizontally and vertically in the water column and following light, olfactory and auditory cues (BLAXTER \& HUNTER, 1982; WRIGHT et al., 2011) larval fish can actively seek out favorable habitats, food and avoid predators. The hydrodynamic does not take into account these factors, but it can offer insight to how oceanic circulation is affecting ecological connectivity between rocky reef habitats in the region and possible trajectories traveled by passive, pelagic fish eggs and very early stage larvae with undeveloped swimming abilities.

Simulated trajectories leading towards Currais mainly descend along the coast line past the northeast mouth of Paranaguá Bay. Paranaguá Bay holds approximately $250 \mathrm{~km}^{2}$ of mangrove forest, important nursery ground for many fish species. Individuals that eventually leave the bay area will encounter currents leading directly toward the Currais islands and ARs. In several of the simulations, bottom trajectories enter from off shore regions, this occurred in both June and March simulations. Trajectories leading towards Currais and AR from offshore regions could explain the presence of species such as $E$. anchoita, a species that spawns off shore and not in coastal areas.

Despite the controversy surrounding biological production of AR, in recent years, they have in fact been shown to contribute to an increase in biomass (CRESSON et al, 2014; GRANNEMAN \& STEELE, 2014; YU et al. 2015). YU et al. (2015) observed biomass and species diversity pre- and post-deployment of ARs in the northern China Sea, using satellite and in situ measurements, and found that nekton biomass and species diversity increased post-deployment of AR in the study area. CRESSON et al. (2014) showed that the biomass produced on artificial reefs can sustain an entire trophic network; local retention of pelagic organic matter and benthic production was increased around ARs in the study area, which in turn enhanced bottom-up effects.

An increasing number of studies are supporting the hypothesis of biological production on ARs, still deployment of artificial reefs is an anthropic influence on the 
natural environment and AR projects should thus always be executed with careful consideration of all possible complications in each individual case.

MPAs are often used and recommended as a fundamental tool for conservation of threatened marine ecosystems and for fishery management, often as a response to declining fish stocks (CUDNEY-BUENO et al., 2009; BORTONE et al., 2011; BROUCHIER et al., 2015). In addition to increasing fish biomass within the MPA, research has also shown that a MPA can benefit adjacent fisheries by larval dispersal or migration of adult species into fishing areas; known as the spillover effect (GOÑI et al., 2010; BROUCHIER et al., 2015). The Marine National Park of Currais is under full protection by law, but to this day there is no clear management plan for the park and no-take fishing legislations are not always respected.

\section{CONCLUSION}

It was hypothesized that the abundance of fish larvae and fish eggs would be higher in AR samples compared to control samples, that the samples would contain fish eggs and early stage larval fish and that the species composition on the ARs would be similar to that of Currais archipelago.

Abundance of both fish larvae and eggs was in fact higher in AR samples compared to control samples, and samples did contain fish larvae in yolk-sac stage as well as more developed larval stages. The two methodologies, light traps and underwater scooter with attached net, were chosen with the goal of collecting larvae of different developmental stages; this was accomplished and difficulties with sampling were caused by challenging environmental conditions rather than by the equipment itself. The total sample size was not large enough to statistically compare the species composition and diversity of the ARs and Currais, but common species were in fact found between the two locations. Additionally, both locations had a strong presence of reef-associated species. As expected, species richness in samples from Currais was higher than in samples from the ARs. 
The findings of this study support that the artificial reefs deployed along the coast of Paraná State have managed to provide a suitable consolidated habitat for epilithic organisms, motile invertebrates and fish. In the years since deployment of the reefs, the new ecosystem has evolved continually. The samples collected in this study showed a variety of species with a variety of behavior- and feeding habits. The presence of reefassociated species on the ARs, both in this study and in previous studies, further supports the hypothesis of the ARs ability to provide a habitat similar to naturally occurring rocky reefs in the area. This was the first study of ichthyoplankton of the ARs and Currais, and it expanded the total species list of the study area with six species and four families.

The results of this study contribute to a more wholesome knowledge of the fish community of natural and artificial reef environments in Paraná State. Furthermore, this information can be used to better define guidelines for sustainable use and management of the ARs and the Currais archipelago, both of which are frequently being used by both commercial and local small-scale fisheries as well as for recreational activities.

\section{REFERENCES}

BAINE, M. 2001. Artificial reefs: a review of their design, application, management and performance. Ocean \& Coastal Management, v. 44(3-4), p. 241 - 259.

BELDADE, R., BORGES, R., GONCALVES, E.J. 2006. Depth distribution of nearshore temperate fish larval assemblages near rocky substrates. Journal of Plankton Research, v. 28(11), p. 1003-1013.

BLAXTER, J. H. S., and HUNTER, J. R. 1982. The Biology of the Clupeoid Fishes. Advances in Marine Biology, v.20, pp.1-223.

BLUMBERG, A. F. and MELLOR, G. L. 1987. A description of a three-dimensional coastal ocean circulation model. In: Heaps, N. ed. Three-dimensional coastal ocean models, Washington, D.C., American Geophysical Union, v.4, p.1-16.

BOHNSACK, J. A. 1982. Are high densities of fishes at artificial reefs the result of habitat limitation or behavioral preference. Bulletin of Marine Science, v. 44(2), p. 631-645. 
BOLTOVSKOY, D. 1999. South Atlantic Zooplankton. Leiden: Backhuys Publishers. $2^{\text {nd }}$. Edition. 1706 p.

BORGES, R., BELDADE, R., GONÇALVES, E. J. 2007. Vertical structure of very nearshore larval fish assemblages in a temperate rocky coast. Mar. Biol., v. 151, p. 13491363.

BORTONE, S. A. et al. 2011. Artificial Reefs in Fisheries Management. CRC Press. 332 p.

BRANDINI, F. P. 1990. Hydrography and characteristics of the phytoplankton in shelf and oceanic waters off southeastern Brazil during winter (July/August 1982) and summer (February/March 1984). Hydrobiologia, v. 196(2), p. 111-148.

BRANDINI, F. P. 2014. Marine biodiversity and sustainability of fishing resources in Brazil: a case study of the coast of Paraná state. Regional Environmental Change, 14:21272137.

BRANDINI, F. P. et al. 2014. Deep chlorophyll maximum and plankton community response to oceanic bottom intrusions on the continental shelf in the South Brazilian Bight. Continental Shelf Research 89 (2014) 61-75.

BRANDINI, F. P. and SILVA, A. S. 2011. Epilithic community development on artificial reefs deployed along a cross-shelf environmental gradient off Paraná state, southern Brazil. Brazilian Journal of Oceanography, v. 59, p. 43-53.

BRANDINI, F. P. et al. 2007. Sources of nutrients and seasonal dynamics of chlorophyll in the inner shelf off Parana State-South Brazil Bight. J Coast Res., v. 23, p. 200-226.

BROCHIER, T. et al. 2015. Implementation of artificial habitats: Inside or outside the marine protected areas? Insights from mathematical approach. Ecological Modelling, v. 297, p. 98-106.

BROGAN, M. V. 1994. Two methods of sampling fish larvae over reefs: a comparison from the Gulf of California. Marine Biology, v. 118, p. 33-44.

BRICKHILL, M. J., LEE, S. Y., CONNOLLY, R. M. 2005. Fishes associated with artificial reefs: attributing changes to attraction or production using novel approaches. Journal of Fish Biology, v. 67 (Supplement B), p. 53-71.

CAMARGO, R., HARARI, J. 2003. Modeling the Paranaguá Estuarine Complex, Brazil: tidal circulation and cotidal charts. Rev. bras. oceanogr., v. 51, p. 23-31. 
CARR, M. H. and HIXTON, M. A. 1997. Artificial reefs: The Importance of Comparisons with Natural Reefs. Fisheries, special issue on Artificial Reef Management, v. 22(4)

CASTRO, B. M. et al. 2006., The Global Coastal Ocean: Interdisciplinary Regional Studies and Syntheses, Chapter 8: Multidisciplinary oceanographic processes on the western Atlantic continental shelf between $4^{\circ} \mathrm{N}$ and $34^{\circ} \mathrm{S}$. In: The Sea, v. 14. px-x (in press).

CASTRO FILHO, B. M., MIRANDA, L. B., MIYAO, S. Y. 1987. Condições hidrográficas na plataforma continental ao largo de Ubatuba: variações sazonais e em média escala. Boletim do Instituto Oceanográfico, v. 35(2), p. 135-151.

CERDA, C. and CASTRO, B. M. 2014. Hydrographic climatology of South Brazil Bight shelf waters between Sao Sebastião (248S) and Cabo Sao Tome (228S). Cont. Shelf Res., v. 89 , p. 5-14.

CLAUDET, J. and PELLETIER, D. 2004. Marine protected areas and artificial reefs: A review of the interactions between management and scientific studies. Aquat. Living Resour., v. 17, p. 129-138.

CONTENTE R. F. et al. 2015. Occurrence of the non-indigenous Omobranchus punctatus (Blenniidae) on the São Paulo coast, South-Eastern Brazil. Marine Biodiversity Records, v. $8(73)$.

COSTA, M. D. P. et al. 2011. Assessment of larval distribution of invasive Omobranchus punctatus (Valenciennes, 1836) (Pisces: Blenniidae) in a subtropical estuary (Southern Brazil). Aquatic Invasions, v. 6(1), p. $33-38$.

CRESSON, P., RUITTON, S., HARMELIN-VIVIEN, M. 2014. Artificial reefs do increase secondary biomass production: mechanisms evidenced by stable isotopes. Mar Ecol Prog Ser, v. 509, p. 15-26.

CUDNEY-BUENO R., et al. 2009. Rapid Effects of Marine Reserves via Larval Dispersal. PLoS ONE, v. 4(1), e. 4140.

DAIGLE, S. T. et al. 2013. What Is the Relative Importance of Phytoplankton and Attached Macroalgae and Epiphytes to Food Webs of Offshore Oil Platforms. Marine and Coastal Fisheries 5:1, 53-64, DOI: 10.1080/19425120.2013.774301

DAROS, F.A., et.al. 2012. Checklist of rocky reef fishes from the Currais Archipelago and Itacolomis Island, Paraná state, Brazil. Check List, v. 8(3), p. 349-354. 
DOHERTY, P. J. 1987. Light-traps: selective but useful devices for quantifying the distributions and abundances of larval fishes. Bulletin of Marine Science, v. 41(2), p. 423431.

FAVERO, J., et al. 2015. Using new tools to identify eggs of Engraulis anchoita (Clupeiformes, Engraulidae). Journal of Fish Biology, v. 86, p. 822-826.

FISHER, R. and BELLWOOD, D. R. 2002. A light trap design for stratum-specific sampling of reef fish larvae. Journal of Experimental Marine Biology and Ecology, v. 269(1), p. 27-37.

FLOETER, S. and GASPARINI, J. L. 2000. The southeastern Atlantic reef fish fauna: composition and zoogeographic patterns. Journal of Fish Biology, v. 56, p. 1099-1114.

FLOETER, S.R. et al. 2004. Latitudinal gradients in Atlantic reef fish communities: trophic structure and spatial use patterns. Journal of Fish Biology, v. 64, p. 1680-1699.

FLOETER, S.R. et al. 2001. Geographic variation in reef-fish assemblage along the Brazilian coast. Global Ecology \& Biogeography, v. 10, p. 423-431.

GERHARDINGER, L. C., et al. 2006. Omobranchus punctatus (Teleostei: Blenniidae), an exotic blenny in the Southwestern Atlantic. Biological Invasions, v. 8, p. 941-946.

GOÑI, R., et al. 2010. Net contribution of spillover from a marine reserve to fisheries catches. Mar Ecol Prog Ser, v. 400, p. 233-243.

GRANNEMANN, J. E., STEELE M. A. 2014. Fish growth, reproduction, and tissue production on artificial reefs relative to natural reefs. ICES Journal of Marine Science; doi:10.1093/icesjms/fsu082.

HACKRADT, C. W., FÉLIX-HACKRADT, F. C. 2009. Assembléia de peixes associados a ambientes consolidados no litoral do Paraná, Brasil: uma análise qualitativa com notas sobre sua bioecologia. Papeis Avulsos de Zoologia, v. 49(31), p. 389-403.

HARARI J., et al. 2006. Numerical modeling of the hydrodynamics in the coastal area of Sao Paulo State - Brazil. Journal of Coastal Research, SI 39 (Proceedings of the $8^{\text {th }}$ International Coastal Symposium), p. 1560-1563.

HARARI J., CAMARGO R. 2003. Numerical simulation of the tidal propagation in the coastal region of Santos (Brazil, $24^{\circ} \mathrm{S} 46^{\circ} \mathrm{W}$ ). Continental Shelf Research, v. 23, p. 15971613. 
HERNANDEZ, F. J. and LINDQUIST, D. G. A. 1999. Comparison of two light-trap designs for sampling larval and presettlement juvenile fish above e reef in Onslow bay, North Carolina. Bulletin of Marine Science, v. 64(1), p. 173-184.

HERNANDEZ F. J., and SHAW R. F. 2003. Comparison of Plankton Net and Light Trap Methodologies for Sampling Larval and Juvenile Fishes at Offshore Petroleum Platforms and a Coastal Jetty off Louisiana. American Fisheries Society Symposium, v. 36, p. 15-38.

HINRICHSEN, D. 1998. Coastal Waters of the World: Trends, Threats, and Strategies. Washington D.C. Island Press, 298 p.

JENSEN, A. 1998. European Artificial Reef Research Network (EARRN): final report and recommendations. University of Southampton.

JENSEN, A. C. 2002. Artificial reefs of Europe: perspective and future. ICES Journal of Marine Science, v. 59, p. 3-13.

KENDAll, A., AHLSTROM, E. H., MOSER, H. G. 1984. Early life history stages of fishes and their characters. In: Ontogeny and Systematics of Fishes. American Society of Ichthyologists and Herpetologists, Special Publication No. 1.

KANG, C. K. et al. 2008. Food web structure of a restored macroalgal bed in the eastern Korean peninsula determined by $\mathrm{C}$ and $\mathrm{N}$ stable isotope analyses. Mar Biol., v. 153, p. 1181-1198.

LASSO-ALCALA, O. et al. 2011. Invasion of the Indo-Pacific blenny Omobranchus punctatus (Perciformes: Blenniidae) on the Atlantic Coast of Central and South America. Neotropical Ichthyology, v. 9, p. 571-578.

LEIS, J. M., SIEBECK, U., DIXON D. L. 2011. How Nemo Finds Home: The Neuroecology of Dispersal and of Population Connectivity in Larvae of Marine Fishes. Integrative and Comparative Biology, pp $1-18$.

LEIS, J. M. and CARSON-EWART, B. M. 2000. The larvae of Indo-Pacific coastal fishes. Series: Fauna Malesiana handbooks. Leiden: Brill, 850 p.

LALLI, C. M., and PARSONS, T. R. 1997. Biological Oceanography: An Introduction, $2^{\text {nd }}$ edition. Elsevier Butterworth-Heinemann. 337 p.

LINDQUIST, D. C. and SHAW, R. F. 2005. Effects of current speed and turbidity on stationary light-trap catches of larval and juvenile fishes. Fish. Bull, v. 103, p. 438-444. 
MATSUURA, Y., SPACH, H.L., KATSURAGAWA, M. 1992. Comparison of spawning patterns of the Brazilian sardine (Sardinella brasiliensis) and anchoita (Engraulis anchoita) in Ubatuba region, southern Brazil during 1985 through 1988. Bolm Inst. Oceanogr., S Paulo, v. 40(1/2), p. 101-115.

NAGELKERKEN, I., et al. 2015. The seascape nursery: a novel special approach to identify and manage nurseries for costal marine fauna. FISH and FISHERIES, v. 16, p. $362-371$.

NOERNBERG, M. A. 2001. Processos morfodinâmicos no complexo estuarino de Paranaguá, Paraná, Brasil: um estudo a partir de dados in situ e Landsat-TM. Tese de doutorado, Universidade Federal do Paraná, Critiba, PR.

OSENBERG, C. W., et al. 2002. A quantitative framework to evaluate the attractionproduction controversy. ICES Journal of Marine Science, v. 59, p. 214-221.

PICKERING, H. and WHITMARSH, D. 1997. Artificial reefs and fisheries exploitation: A review of the "attraction versus production" debate, the influence of design and its significance for policy. Fisheries Research, v. 31(1-2), p. 39-59.

PINHEIRO, P. C. 2005. Ictiofauna do arquipélago de Currais (Paraná - Brasil): complexidade estrutural dos costões rochosos e análise comparativa com um módulo recifal artificial. Tese de doutorado, Universidade Federal de São Carlos.

POLOVINA, J. J. and SAKAI, I. 1989. Impacts of artificial reefs on fishery production in shimamaki, Japan. Bulletin Of Marine Science, v. 44(2), p. 997-1003.

RICKHARDS, W. J. 2006. Early Stages of Atlantic Fishes: An Identification Guide for the Western Central North Atlantic, volume I. CRC Press, 1335 p.

RICHARDS, W. J. 2006. Early Stages of Atlantic Fishes: An Identification Guide for the Western Central North Atlantic, volume II. CRC Press, $2640 \mathrm{p}$

SALE, P. F. 2006. Coral reef fishes: Dynamics and Diversity in a Complex Ecosystem. Gulf Professional Publishing, 549 p.

SEVEROV, D. N, et al. 2014. SST anomaly variability in Southwestern Atlantic and El Niño /Southern oscillation. Advances in Space Research, v. 33, p. 343-347. 
SILVA, E. T., et al. 1997. Recifes Artificiais Marinhos (RAM): Uma proposta de conservação da biodiversidade e desenvolvimento da pesca artesanal na costa do Estado do Paraná. In: Anais da Semana Nacional de Oceanografia, UNIVALI/ FACIMAR, Itajaí, SC.

STANLEY, J. A., RADFORD, C. A., JEFFS, A. G. 2012. Location, location, location: finding a suitable home among the noise. Proc. R. Soc. B, v. 279, p. 3622-3631.

WHITEHEAD, P. J. P., NELSON, G. J. and WONGRATANA, T. 1988. FAO species catalogue. Vol. 7. Clupeoid fishes of the world (Suborder Clupeoidei). An annotated and illustrated catalogue of the herrings, sardines, pilchards, sprats, anchovies and wolfherrings. Part 2. Engraulidae. FAO Fish.Synop., v. 7, p. 305-579.

World Ocean Review (WOR) 1. 2010. Living with the Oceans - A report on the state of the world's oceans.

WRIGHT, K. J., HIGGS, D. M., LEIS, J. M. 2011. Ontogenetic and interspecific variation in hearing ability in marine fish larvae. Mar Ecol Prog Ser, v. 424, p. 1-13.

YU, J. et al. 2015. Ecological effects of artificial reefs in Daya Bay of China observed from Satellite and in situ measurements. Advances in Space Research, v. 55, p. 2315-232.

\section{ELECTRONIC REFERENCES}

Parque Nacional Marinho das Ilhas dos Currais. www.icmbio.gov.br (last accessed on 17.08.2016)

www.fishbase.org (last accessed on 17.08.2016).

\section{LEGISLATIONS}

BRASIL. Law ${ }^{\circ} 9.985$, from July $18^{\text {th }} 2000$, Art. $2^{\circ}$.

BRASIL. Law ${ }^{\circ} 12.829$, from June $20^{\text {th }} 2013$. 

APPENDIX A 
Table I - Families and species of natural and artificial reef habitats in Paraná State, Brazil

\begin{tabular}{|c|c|c|c|c|c|c|c|}
\hline \multirow[b]{3}{*}{ Family/Species } & \multicolumn{5}{|c|}{ Adult } & \multirow{2}{*}{\multicolumn{2}{|c|}{$\begin{array}{c}\text { Larvae } \\
\text { BOERSETH } \\
(2016) \\
\end{array}$}} \\
\hline & \multicolumn{2}{|c|}{$\begin{array}{l}\text { PINHEIRO } \\
\text { (2005) }\end{array}$} & \multicolumn{2}{|c|}{$\begin{array}{c}\text { HACKRADT } \\
(2009)\end{array}$} & \multirow{2}{*}{$\begin{array}{l}\text { DAROS } \\
\text { (2012) } \\
\text { Currais } \\
\end{array}$} & & \\
\hline & AR & Currais & AR & Currais & & AR & Currais \\
\hline \multicolumn{8}{|l|}{ Achanturidae } \\
\hline Achanturus bahuanus (Castelnau, 1855) & & & & $\mathrm{x}$ & $\mathrm{x}$ & & \\
\hline Acanthurus chirurgus (Bloch, 1787) & & & $x$ & $x$ & $x$ & & \\
\hline \multicolumn{8}{|l|}{ Balistidae } \\
\hline Balistes capriscus (Gmelin, 1789) & & & $x$ & & & & \\
\hline Balistes vetula (Linnaeus, 1758) & $x$ & $x$ & & & & & \\
\hline $\begin{array}{l}\text { Blenniidae } \\
\text { Hypsoblennius invemar (Smith-Vaniz \& }\end{array}$ & & & & & & & \\
\hline Acero, 1980) & & & $\mathrm{x}$ & & & & \\
\hline Parablennius marmoreus (Poeu, 1876) & & & $x$ & $x$ & $x$ & & \\
\hline Parablennius pilicornis (Cuvier, 1829) & & & $x$ & $x$ & $x$ & & \\
\hline $\begin{array}{l}\text { Scartella cristata (Linnaeus, 1758) } \\
\text { Omobranchus punctatus (Valenciennes, } \\
\text { 1836) }\end{array}$ & & & & $x$ & $\mathrm{x}$ & $x$ & $x$ \\
\hline \multicolumn{8}{|l|}{ Carangidae } \\
\hline Carangoides ruber (Bloch, 1793) & $x$ & $x$ & & & & $x$ & $x$ \\
\hline Carangoides crysos (Mitchill, 1815) & & & $x$ & $x$ & $x$ & & \\
\hline Caranx latus (Agassiz, 1831) & & & $x$ & $x$ & & & \\
\hline Chloroscombrus chrysurus (Linnaeus, 1766) & & & $x$ & $x$ & $x$ & $x$ & $x$ \\
\hline \multicolumn{7}{|l|}{ Pseudocaranx dentex (Bloch and } & \\
\hline Schemeider, 1801) & & & $x$ & $x$ & $x$ & & \\
\hline Seriola rivoliana(Linnaeus, 1758) & & & $x$ & & & & \\
\hline Trachinotus falcatus (Linnaeus, 1758) & & & & $x$ & & & \\
\hline \multicolumn{8}{|l|}{ Chaenopsidae } \\
\hline Emblemariops signifera (Ginsburg, 1942) & & & $x$ & $x$ & & & \\
\hline \multicolumn{8}{|l|}{ Chaetodontidae } \\
\hline Chaetodon striatus (Linnaeus, 1758) & $x$ & $x$ & & & & & \\
\hline \multicolumn{8}{|l|}{ Clupeidae } \\
\hline Harengula jaguana (Poey, 1865) & & & & & & $x$ & $x$ \\
\hline Harengula clupeola (Cuvier, 1829) & & & $x$ & $x$ & & & \\
\hline Sardinella brasiliensis (Steindachner, 1879) & & & & & & & $x$ \\
\hline Sardinella janeiro (Eigenmann, 1824) & & & $x$ & $x$ & & & \\
\hline \multicolumn{8}{|l|}{ Dactyloscopidae } \\
\hline Dactyloscopidae sp. & & & & & & & $x$ \\
\hline \multicolumn{8}{|l|}{ Diodontidae } \\
\hline Chilomycterus spinosus (Linnaeus, 1758) & & & & $x$ & & & \\
\hline
\end{tabular}


Table I - Continued.

\begin{tabular}{|c|c|c|c|c|c|c|c|}
\hline \multirow[b]{3}{*}{ Family/Species } & \multicolumn{5}{|c|}{ Adult } & \multirow{2}{*}{\multicolumn{2}{|c|}{$\begin{array}{l}\text { Larvae } \\
\text { BOERSETH } \\
\text { (2016) }\end{array}$}} \\
\hline & \multicolumn{2}{|c|}{$\begin{array}{l}\text { PINHEIRO } \\
(2005)\end{array}$} & \multicolumn{2}{|c|}{$\begin{array}{c}\text { HACKRADT } \\
\text { (2009) }\end{array}$} & \multirow{2}{*}{$\begin{array}{l}\text { DAROS } \\
(2012) \\
\text { Currais } \\
\end{array}$} & & \\
\hline & AR & Currais & AR & Currais & & AR & Currais \\
\hline Echeneidae & & & & & & & \\
\hline Echeneis naucrates (Linnaeus, 1758) & & & $x$ & & & & \\
\hline Engraulidae & & & & & & & \\
\hline Engraulis anchoita (Hubbs \& Marini, 1935) & & & & & & $x$ & $x$ \\
\hline Engraulidae sp. & & & & & & $x$ & \\
\hline Ephippidae & & & & & & & \\
\hline Chaetodipterus faber (Broussonet, 1782) & $x$ & $x$ & & & $x$ & & \\
\hline Fistulariidae & & & & & & & \\
\hline Fistularia tabacaria (Linnaeus, 1758) & & & $x$ & & $x$ & & \\
\hline $\begin{array}{l}\text { Gobiidae } \\
\text { Bathygobius soporator (Valenciennes, } \\
\text { 1837) }\end{array}$ & & & & $x$ & & & \\
\hline Coryphopterus glaucofraenum (Gill, 1863) & & & $x$ & $x$ & $x$ & & $x$ \\
\hline $\begin{array}{l}\text { Gerreidae } \\
\text { Eucinostomus argenteus (Baird \& Girard, } \\
\text { 1855) }\end{array}$ & & & & & & & \\
\hline Diapterus rhombeus (Cuvier, 1829) & & & $x$ & & & & $x$ \\
\hline Haemulidae & & & & & & & \\
\hline Anisotremus surinamensis (Bloch, 1791) & & & $x$ & $x$ & $x$ & & \\
\hline Anisotremus virginicus (Bloch, 1791) & & & $x$ & $x$ & $x$ & & \\
\hline $\begin{array}{l}\text { Haemulon aurolineatum (Cuvier, 1830) } \\
\text { Haemulon steindachneri (Jordan \& }\end{array}$ & & & $x$ & $x$ & $x$ & & $x$ \\
\hline Guilbert, 1882) & & & $x$ & $x$ & $x$ & & \\
\hline Orthopristis ruber (Cuvier, 1830) & & & $x$ & $x$ & $x$ & & \\
\hline Hemiramphidae & & & & & & & \\
\hline $\begin{array}{l}\text { Hemiramphus brasiliensis (Linnaeus, 1758) } \\
\text { Hyporhamphus unifasciatus (Ranzani, } \\
\text { 1842) }\end{array}$ & & & $x$ & $x$ & & & \\
\hline Holocentridae & & & & & & & \\
\hline Holocentrus adscensionis (Osbeck, 1795) & $x$ & $x$ & $x$ & $x$ & $x$ & & \\
\hline Kyphosidae & & & & & & & \\
\hline Kyphosus secatrix (Linnaeus, 1758) & $x$ & $x$ & & & & & \\
\hline Labrisomidae & & & & & & & \\
\hline $\begin{array}{l}\text { Labrisomidae } s p . \\
\text { Labrisomus nuchipinnis (Quoy \& Gaimand, } \\
\text { 1824) }\end{array}$ & $x$ & $x$ & & $x$ & $x$ & & $x$ \\
\hline $\begin{array}{l}\text { Malacoctenus delalandii (Valenciennes, } \\
\text { 1836) }\end{array}$ & & & $x$ & $\mathrm{x}$ & $x$ & & \\
\hline
\end{tabular}


Table I - Continued.

\begin{tabular}{|c|c|c|c|c|c|c|c|}
\hline \multirow[b]{3}{*}{ Family/Species } & \multicolumn{5}{|c|}{ Adult } & \multirow{2}{*}{\multicolumn{2}{|c|}{$\begin{array}{l}\text { Larvae } \\
\text { BOERSETH } \\
\text { (2016) }\end{array}$}} \\
\hline & \multicolumn{2}{|c|}{$\begin{array}{l}\text { PINHEIRO } \\
\text { (2005) }\end{array}$} & \multicolumn{2}{|c|}{$\begin{array}{l}\text { HACKRADT } \\
\text { (2009) }\end{array}$} & \multirow{2}{*}{$\begin{array}{l}\text { DAROS } \\
(2012) \\
\text { Currais } \\
\end{array}$} & & \\
\hline & AR & Currais & AR & Currais & & AR & Currais \\
\hline $\begin{array}{l}\text { Labrisomidae } \\
\text { Paraclinus spectator (Guimarães \& } \\
\text { Bacellar, 2002) }\end{array}$ & & & & & $\mathrm{x}$ & & \\
\hline Labridae & & & & & & & \\
\hline Bodianus pulchellus (Poey, 1860) & $x$ & $x$ & & & & & \\
\hline Halichoeres cyanocephalus (Bloch, 1791) & $x$ & $x$ & & & & & \\
\hline $\begin{array}{l}\text { Halichoeres poeyi (Stendachner, 1867) } \\
\text { Thalassoma noronhanum (Boulenger, } \\
\text { 1890) }\end{array}$ & $\mathrm{x}$ & $x$ & $x$ & $x$ & $x$ & & \\
\hline Lutjanidae & & & & & & & \\
\hline Lutjanus analis (Cuvier, 1828) & & & $x$ & $x$ & $x$ & & \\
\hline Lutjanus synagris (Linnaeus, 1758) & & & $x$ & & & & \\
\hline Rhomboplites aurorubens (Cuvier, 1828) & & & $x$ & & & & \\
\hline Monocanthidae & & & & & & & \\
\hline Stephanolepis hispidus (Linnaeus, 1766) & & & & $x$ & $x$ & & \\
\hline Mullidae & & & & & & & \\
\hline Pseudupeneus maculatus (Bloch, 1793) & & & $x$ & $x$ & $x$ & & \\
\hline Muraenidae & & & & & & & \\
\hline Gymnothorax funebris (Ranzini, 1840) & & & $x$ & & $x$ & & \\
\hline Gymnothorax moringa(Cuvier, 1829) & & & $x$ & & $x$ & & \\
\hline Gymnothorax vicinus (Castelnau, 1855) & & & $x$ & $x$ & $x$ & & \\
\hline Ogcocephalidae & & & & & & & \\
\hline Ococephalus vespertilio (Linnaeus, 1758) & & & & $x$ & & & \\
\hline Ophichthidae & & & & & & & \\
\hline Myrichthys breviceps (Richardson, 1848) & & & & & $x$ & & \\
\hline Myrichthys ocellatus (Lesueur, 1825) & & & & $x$ & & & \\
\hline $\begin{array}{l}\text { Pempheridae } \\
\text { Pempheris schomburgkii (Müller \& }\end{array}$ & & & & & & & \\
\hline Troschel, 1848) & & & & $x$ & $x$ & & \\
\hline Pomacanthidae & & & & & & & \\
\hline Pomachantus paru (Bloch, 1787) & & & $x$ & $x$ & $x$ & & \\
\hline Pomacentridae & & & & & & & \\
\hline Abudefdud saxatilis (Linnaeus, 1758) & $x$ & $x$ & & $x$ & $x$ & & \\
\hline Chromis multilineata (Guichenot, 1853) & $x$ & $x$ & & $x$ & & & \\
\hline Stegastes fuscus (Cuvier, 1830) & $x$ & $x$ & & $x$ & $x$ & & \\
\hline Stegastes pictus (Castelnau, 1855) & $x$ & $\mathrm{x}$ & & & & & \\
\hline Stegastes variabilis (Castelnau, 1855) & $\mathrm{x}$ & $\mathrm{x}$ & & $\mathrm{x}$ & $\mathrm{x}$ & & \\
\hline
\end{tabular}


Table I - Continued.

\begin{tabular}{|c|c|c|c|c|c|c|c|}
\hline \multirow[b]{3}{*}{ Family/Species } & \multicolumn{5}{|c|}{ Adult } & \multirow{2}{*}{\multicolumn{2}{|c|}{$\begin{array}{c}\text { Larvae } \\
\text { BOERSETH } \\
(2016) \\
\end{array}$}} \\
\hline & \multicolumn{2}{|c|}{$\begin{array}{c}\text { PINHEIRO } \\
(2005)\end{array}$} & \multicolumn{2}{|c|}{$\begin{array}{l}\text { HACKRADT } \\
(2009)\end{array}$} & \multirow{2}{*}{$\begin{array}{l}\text { DAROS } \\
\text { (2012) } \\
\text { Currais } \\
\end{array}$} & & \\
\hline & AR & Currais & AR & Currais & & AR & Currais \\
\hline \multicolumn{8}{|l|}{ Pomatomidae } \\
\hline Pomatomus saltatrix (Linnaeus, 1766) & & & $x$ & & & & \\
\hline \multicolumn{8}{|l|}{ Rachycentridae } \\
\hline Rachycentron canadum (Linnaeus, 1766) & & & $x$ & & & & \\
\hline \multicolumn{8}{|l|}{ Rhinobatidae } \\
\hline Rhinobatus percellens (Walbaum, 1792) & & & $x$ & & & & \\
\hline \multicolumn{8}{|l|}{ Scaridae } \\
\hline Scaridae sp. & & & & & & $x$ & $x$ \\
\hline Cryptotomus roseus (Cope, 1871) & $x$ & $x$ & & & & & \\
\hline Nicholsina usta usta (Valenciennes, 1840) & $x$ & $x$ & & & & & \\
\hline $\begin{array}{l}\text { Sparisoma axillare (Steindachner, 1878) } \\
\text { Sparisoma chrysopterum(Block \& }\end{array}$ & & & $x$ & $x$ & $x$ & & \\
\hline Schneider, 1801) & $x$ & $x$ & & & & & \\
\hline Sparisoma rubripinne (Valenciennes, 1840) & $x$ & $x$ & & & & & \\
\hline Sparisoma frondosum (Agassiz, 1831) & & & & $x$ & $x$ & & \\
\hline Sparisoma radians (Valenciennes, 1840) & $x$ & $x$ & & $x$ & & & \\
\hline \multicolumn{8}{|l|}{ Sciaenidae } \\
\hline Bairdiella ronchus(Cuvier, 1830) & & & & & & $x$ & \\
\hline Odontoscion dentex (Cuvier, 1830) & & & $x$ & $x$ & $x$ & & \\
\hline $\begin{array}{l}\text { Paraques acuminatus (Bloch \& Schneider, } \\
\text { 1801) }\end{array}$ & & & $x$ & $x$ & $x$ & & \\
\hline \multicolumn{8}{|l|}{ Scorpaenidae } \\
\hline Scorpaena plumieri (Bloch, 1793) & & & & $x$ & & & \\
\hline $\begin{array}{l}\text { Serranidae } \\
\text { Diplectrum radiale (Quoy and Gaimand, } \\
\text { 1824) }\end{array}$ & & & & & $x$ & & \\
\hline Serranus flaviventris (Cuvier, 1829) & & & $x$ & $x$ & $x$ & & \\
\hline Epinephelus itajara (Lichtenstein, 1822) & & & $x$ & $x$ & & & \\
\hline \multicolumn{8}{|l|}{ Hyporthodus nigritus (Holbrook, 1855) } \\
\hline $\begin{array}{l}\text { Hyporthodus niveatus (Valenciennes, } \\
\text { 1828) }\end{array}$ & & & $x$ & & $x$ & & \\
\hline $\begin{array}{l}\text { Mycteroperca acutirostris (Valenciennes, } \\
\text { 1828) }\end{array}$ & & & $x$ & $x$ & $x$ & & \\
\hline Mycteroperca bonaci (Poey, 1860) & & & & $x$ & $x$ & & \\
\hline Mycteroperca interstitialis (Poey, 1860) & & & & $x$ & & & \\
\hline Mycteroperca marginata (Lowe, 1834) & & & $x$ & $x$ & $x$ & & \\
\hline $\begin{array}{l}\text { Mycteroperca microleps (Goode \& Bean, } \\
\text { 1880) }\end{array}$ & & & $x$ & & & & \\
\hline Cephalopholis fulva (Linnaeus, 1758) & $x$ & $x$ & & & & & \\
\hline
\end{tabular}


Table I - Continued.

\begin{tabular}{|c|c|c|c|c|c|c|c|}
\hline \multirow[b]{3}{*}{ Family/Species } & \multicolumn{5}{|c|}{ Adult } & \multirow{2}{*}{\multicolumn{2}{|c|}{$\begin{array}{c}\text { Larvae } \\
\text { B } \varnothing \text { RSETH } \\
(2016) \\
\end{array}$}} \\
\hline & \multicolumn{2}{|c|}{$\begin{array}{c}\text { PINHEIRO } \\
(2005)\end{array}$} & \multicolumn{2}{|c|}{$\begin{array}{c}\text { HACKRADT } \\
(2009)\end{array}$} & \multirow{2}{*}{$\begin{array}{l}\text { DAROS } \\
\text { (2012) } \\
\text { Currais } \\
\end{array}$} & & \\
\hline & AR & Currais & AR & Currais & & AR & Currais \\
\hline \multicolumn{8}{|l|}{ Sparidae } \\
\hline Archosargus probatocephalus (Walbaum, 1792) & & & $x$ & & & & \\
\hline Archosargus rhomboidalis (Linnaeus, 1758) & $\mathrm{x}$ & $x$ & & & & & \\
\hline Calamus pennatula (Guichenot, 1868) & & & $x$ & & & & \\
\hline Diplodus argenteus (Valensiennes, 1830) & $\mathrm{x}$ & $\mathrm{x}$ & $x$ & $\mathrm{x}$ & $\mathrm{x}$ & & \\
\hline \multicolumn{8}{|l|}{ Sphyraenidae } \\
\hline Sphyraena guachancho (Cuvier, 1829) & & & $x$ & & & & \\
\hline Sphyraena tome (Fowler, 1903) & & & $x$ & $x$ & & & \\
\hline \multicolumn{8}{|l|}{ Synghnathidae } \\
\hline Hippocampus reidi (Ginsburg, 1933) & & & $x$ & & & & \\
\hline Micrognathus crinitus (Jenyns, 1842) & & & & $\mathrm{x}$ & $\mathrm{x}$ & & \\
\hline \multicolumn{8}{|l|}{ Synodontidae } \\
\hline Synodus foetens (Linnaeus, 1766) & & & & & & & $x$ \\
\hline \multicolumn{8}{|l|}{ Tetraodontidae } \\
\hline Sphoeroides greeleyi (Gilbert, 1900) & & & & $x$ & & & \\
\hline Sphoeroides spengleri (Bloch, 1785) & & & & $x$ & & & \\
\hline Sphoeroides testudineus (Linnaeus, 1758) & & & & $x$ & & & \\
\hline \multicolumn{8}{|l|}{ Trichiurinae } \\
\hline Trichiurus lepturus (Linnaeus, 1758) & & & & & & $\mathrm{X}$ & \\
\hline
\end{tabular}

